Prepared in cooperation with the East Dakota Water Development District and James River Water Development District

\title{
Climate and Streamflow Characteristics for Selected Streamgages in Eastern South Dakota, Water Years 1945-2013
}

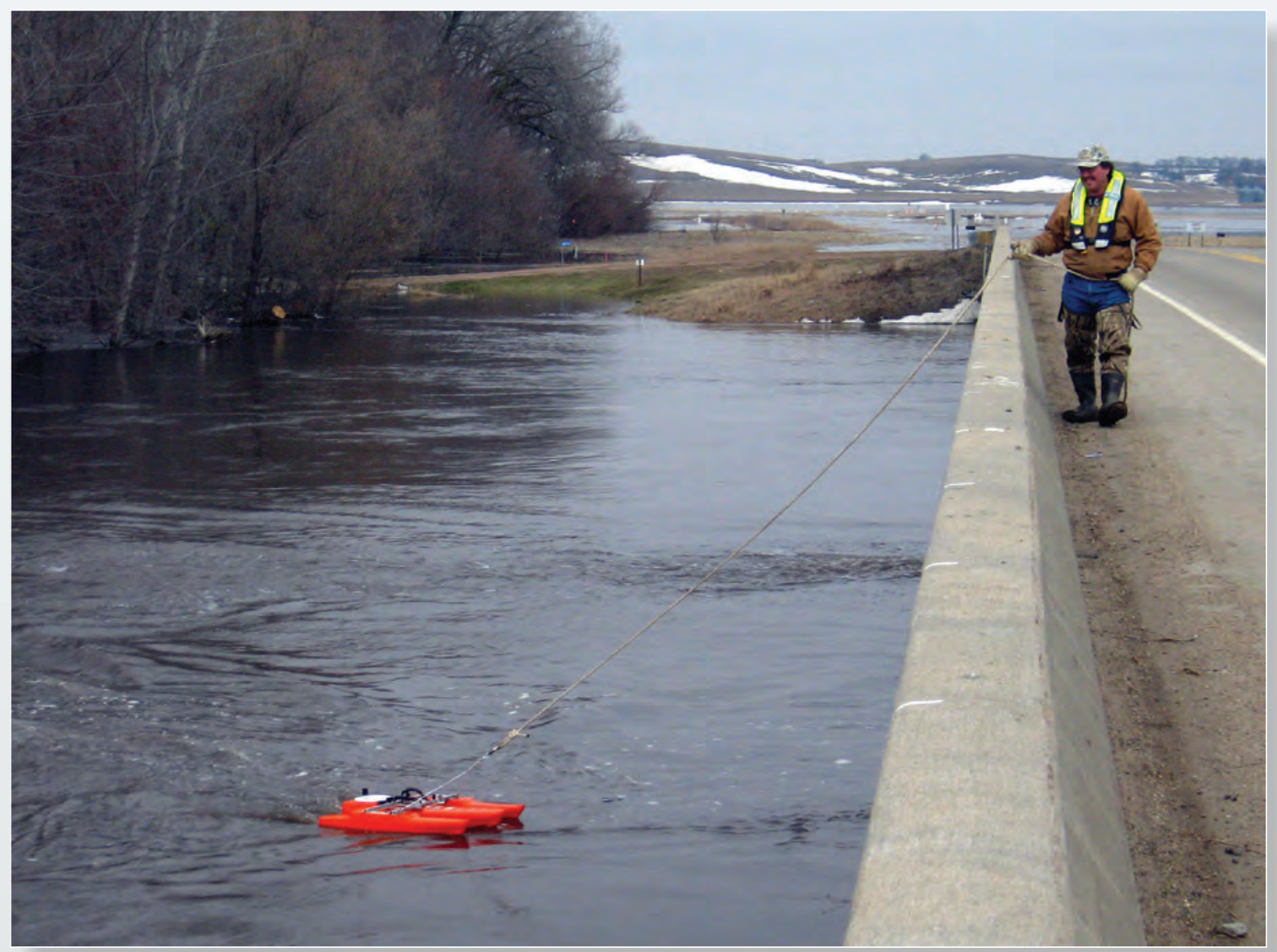

Scientific Investigations Report 2015-5146 
Cover. U.S. Geological Survey hydrologic technician measuring streamflow at the Big Sioux River at Akron, lowa, on March 17, 2010 (front). Flooding over the road at the Big Sioux River at Akron, lowa, on March 17, 2010 (back). Photographs courtesy of Nathan Stevens, U.S. Geological Survey. 


\section{Climate and Streamflow Characteristics for Selected Streamgages in Eastern South Dakota, Water Years 1945-2013}

By Galen K. Hoogestraat and John F. Stamm

Prepared in cooperation with the East Dakota Water Development District and James River Water Development District

Scientific Investigations Report 2015-5146 


\title{
U.S. Department of the Interior SALLY JEWELL, Secretary
}

\section{U.S. Geological Survey \\ Suzette M. Kimball, Acting Director}

\author{
U.S. Geological Survey, Reston, Virginia: 2015
}

For more information on the USGS - the Federal source for science about the Earth, its natural and living resources, natural hazards, and the environment—visit http://www.usgs.gov or call 1-888-ASK-USGS.

For an overview of USGS information products, including maps, imagery, and publications, visit http://www.usgs.gov/pubprod/.

Any use of trade, firm, or product names is for descriptive purposes only and does not imply endorsement by the U.S. Government.

Although this information product, for the most part, is in the public domain, it also may contain copyrighted materials as noted in the text. Permission to reproduce copyrighted items must be secured from the copyright owner.

Suggested citation:

Hoogestraat, G.K., and Stamm, J.F., 2015, Climate and streamflow characteristics for selected streamgages in eastern South Dakota, water years 1945-2013: U.S. Geological Survey Scientific Investigations Report 2015-5146, 35 p., with appendix, http://dx.doi.org/10.3133/sir20155146.

ISSN 2328-0328 (online) 


\section{Contents}

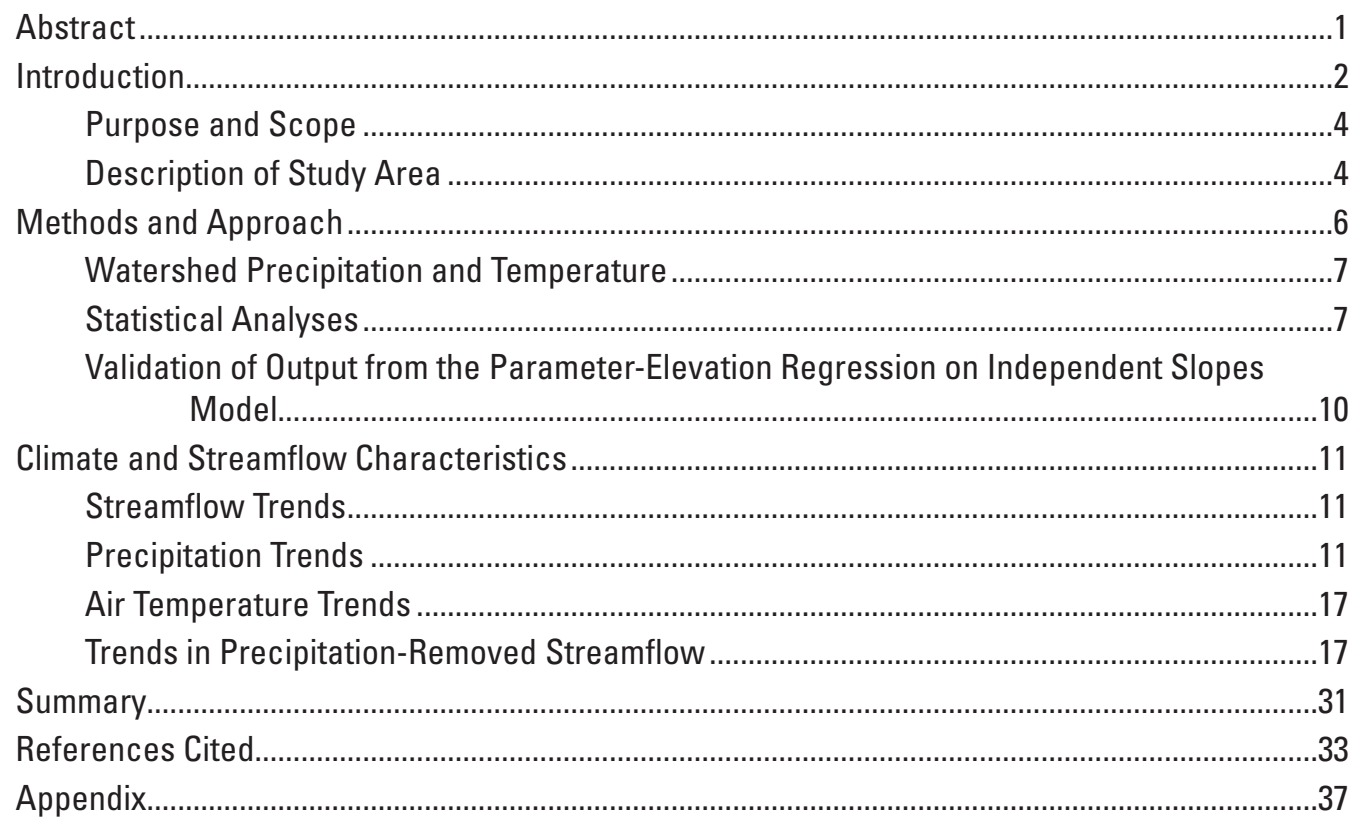

\section{Figures}

1. Map showing study area and locations of 10 streamgages and their associated watersheds in James, Big Sioux, Vermillion, and Minnesota River Basins included

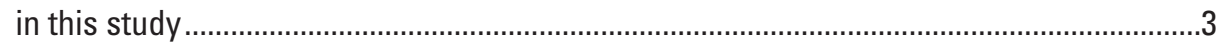

2. Graphs showing land use in study watersheds

3. Graphs showing mean monthly precipitation and air temperature at the Aberdeen Regional Airport Historical Climatology Network weather station and mean monthly streamflow at the James River near Scotland, South Dakota, calendar years 1945-2013.

4. Graph showing annual mean streamflow and Sen slope trendlines for James River near Scotland, South Dakota, water years 1945-2013.

5. Graph showing relation between annual total precipitation at the Aberdeen Regional Airport and the Parameter-Elevation Regression on Independent Slopes Model output for the grid point at the same location, 1945-2013.

6. Graphs showing annual mean and 7-day minimum streamflow for selected streamgages, water years 1945-2013.

7. Graphs showing March-May mean and 7-day minimum streamflow for selected streamgages, water years 1945-2013.

8. Graphs showing total precipitation for watersheds of selected streamgages, water years 1945-2013

9. Graphs showing mean of monthly maximum and minimum air temperature for watersheds of selected streamgages, water years 1945-2013. 
10. Graphs showing relation between mean streamflow and total precipitation for annual and seasonal periods at selected streamgages, water years 1945-2013 ...........20

11. Graphs showing precipitation-streamflow statistical models for three periods .............25

12. Graphs showing time-series plots of annual precipitation-removed streamflow,

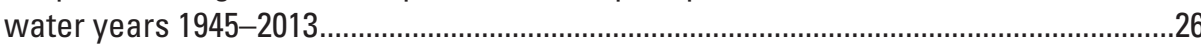

13. Graph showing groundwater levels for three monitoring wells and precipitation totals in the James River Basin, water years 1953-2013

\section{Tables}

1. Streamflow-gaging stations included in analyses...

2. Statistics for trends in annual mean, annual 7-day minimum, March-May mean, and March-May 7-day minimum streamflow, water years 1945-2013 and 1980-2013

3. Statistics for trends in annual and seasonal total precipitation, water years 1945-2013 and 1980-2013.

4. Statistics for trends in annual and seasonal maximum and minimum air temperature, water years 1945-2013 and 1980-2013

5. Coefficients of determination for locally-weighted scatterplot smoothing models using precipitation as an explanatory variable for streamflow statistics within the same water year for water years 1945-2013.

6. Statistics for precipitation-removed streamflow trends, water years 1945-2013 and 1980-2013

7. Statistics for precipitation from current and preceding water years used as explanatory variables in multiple linear regression analyses for annual mean and 7-day minimum streamflow, water years 1945-2013.

8. Coefficients of determination for locally-weighted scatterplot smoothing models using precipitation from current and preceding water years as explanatory variables for streamflow statistics for water years 1945-2013.

9. Information for three monitoring wells in the James River Basin. 


\title{
Conversion Factors
}

Inch/Pound to International System of Units

\begin{tabular}{|c|c|c|}
\hline Multiply & By & To obtain \\
\hline \multicolumn{3}{|c|}{ Length } \\
\hline inch (in.) & 2.54 & centimeter $(\mathrm{cm})$ \\
\hline foot $(\mathrm{ft})$ & 0.3048 & meter $(\mathrm{m})$ \\
\hline mile (mi) & 1.609 & kilometer $(\mathrm{km})$ \\
\hline \multicolumn{3}{|c|}{ Area } \\
\hline square mile $\left(\mathrm{mi}^{2}\right)$ & 2.590 & square kilometer $\left(\mathrm{km}^{2}\right)$ \\
\hline \multicolumn{3}{|c|}{ Flow rate } \\
\hline cubic foot per second $\left(\mathrm{ft}^{3} / \mathrm{s}\right)$ & 0.02832 & cubic meter per second $\left(\mathrm{m}^{3} / \mathrm{s}\right)$ \\
\hline $\begin{array}{l}\text { cubic foot per second per year } \\
{\left[\left(\mathrm{ft}^{3} / \mathrm{s}\right) / \mathrm{yr}\right]}\end{array}$ & 0.02832 & $\begin{array}{l}\text { cubic meter per second per year } \\
\qquad\left[\left(\mathrm{m}^{3} / \mathrm{s}\right) / \mathrm{yr}\right]\end{array}$ \\
\hline inch per year (in/yr) & 25.4 & millimeter per year $(\mathrm{mm} / \mathrm{yr})$ \\
\hline
\end{tabular}

Temperature in degrees Fahrenheit $\left({ }^{\circ} \mathrm{F}\right)$ may be converted to degrees Celsius $\left({ }^{\circ} \mathrm{C}\right)$ as ${ }^{\circ} \mathrm{C}=\left({ }^{\circ} \mathrm{F}-32\right) / 1.8$.

Water year (WY) is the 12-month period from 0ctober 1 through September 30 and is designated by the calendar year in which it ends.

\section{Datum}

Horizontal coordinate information is referenced to the North American Datum of 1983 (NAD 83).

\section{Abbreviations}

\author{
CRP Conservation Reserve Program \\ LOWESS locally-weighed scatterplot smoothing \\ NWIS National Water Information System \\ PRISM Parameter-Elevation Regressions on Independent Slopes Model \\ $R^{2} \quad$ coefficient of determination \\ USGS U.S. Geological Survey \\ USHCN U.S. Historical Climate Network \\ WY water year \\ WY-1 previous water year \\ WY-2 water year from 2 years previous
}





\title{
Climate and Streamflow Characteristics for Selected Streamgages in Eastern South Dakota, Water Years 1945- 2013
}

\author{
By Galen K. Hoogestraat and John F. Stamm
}

\section{Abstract}

Upward trends in precipitation and streamflow have been observed in the northeastern Missouri River Basin during the past century, including the area of eastern South Dakota. Some of the identified upward trends were anomalously large relative to surrounding parts of the northern Great Plains. Forcing factors for streamflow trends in eastern South Dakota are not well understood, and it is not known whether streamflow trends are driven primarily by climatic changes or various land-use changes. Understanding the effects that climate (specifically precipitation and temperature) has on streamflow characteristics within a region will help to better understand additional factors such as land-use alterations that may affect the hydrology of the region. To aid in this understanding, a study was completed by the U.S. Geological Survey, in cooperation with the East Dakota Water Development District and James River Water Development District, to assess trends in climate and streamflow characteristics at 10 selected streamgages in eastern South Dakota for water years (WYs) 1945-2013 (69 years) and WYs 1980-2013 (34 years). A $\mathrm{WY}$ is the 12-month period, October 1 through September 30 , and is designated by the calendar year in which it ends. One streamgage is on the Whetstone River, a tributary to the Minnesota River, and the other streamgages are in the James, Big Sioux, and Vermillion River Basins. The watersheds for two of the James River streamgages extend into North Dakota, and parts of the watersheds for two of the Big Sioux River streamgages extend into Minnesota and Iowa. The objectives of this study were to document trends in streamflow and precipitation in these watersheds, and characterize the residual streamflow variability that might be attributed to factors other than precipitation. Residuals were computed as the departure from a locally-weighted scatterplot smoothing (LOWESS) model. Significance of trends was based on the Mann-Kendall nonparametric test at a 0.10 significance level.

Of the 10 streamgages selected, only the Elm River at Westport (in the upper part of James River Basin) did not have a significant upward trend in annual mean streamflow for WYs 1945-2013, whereas only one-half of the streamgages had significant upward trends in annual mean streamflow for WYs 1980-2013. Mean and 7-day minimum streamflows also had upward trends for the spring runoff period (March-May) for most of the streamgages during WYs 1945-2013 and for one streamgage during WYs 1980-2013. Magnitudes of increases in streamflow were as great as 30 cubic feet per second per year for the streamgage on the James River near Scotland during WYs 1980-2013.

Precipitation trends for WYs 1945-2013 were not necessarily significant for the watersheds of streamgages with a significant streamflow trend. Annual total precipitation had a significant upward trend for the watersheds of 4 of the 10 streamgages during WYs 1945-2013 and no significant trends for WYs 1980-2013. The most widespread precipitation increase was for September-November, with significant upward trends for the watersheds of 8 of the 10 streamgages during WYs 1945-2013; however, no trends in SeptemberNovember precipitation were significant for WYs 1980-2013. The greatest magnitude of increase in precipitation was for the December-May season during WYs 1980-2013, which had a mean increase of 0.106 inch per year in the watersheds of streamgages with significant trends.

The correlation between streamflow and precipitation metrics was low as indicated by the mean coefficient of determination $\left(R^{2}\right)$ of 0.18 for all pairs considered. The highest locally-weighed scatterplot smoothing (LOWESS) correlation was between annual precipitation (by water year) and annual mean streamflow (by water year), which had a mean $R^{2}$ of 0.47 for all streamgages and was as high as 0.72 for one streamgage. The correlation between annual precipitation and March-May mean streamflow had a mean $R^{2}$ of 0.33 for all streamgages and was as high as 0.52 for one streamgage. Other metrics had $R^{2}$ values for LOWESS correlations that were less than 0.3 and were not further considered for analyses of residuals. For annual precipitation as a predictor of annual mean flow, precipitation-removed streamflow had significant upward trends during WYs 1945-2013 for one-half of the streamgages. Upward trends in residual annual mean streamflow were indicated for the Whetstone River and lower part of the Big Sioux River Basin, indicating that other factors are contributors to streamflow variability during WYs 1945-2013. 
In contrast, most of the streamgages in the James and Vermillion River Basins had no trends in residual annual mean streamflow, indicating that streamflow trends can be explained primarily by precipitation. Precipitation-removed streamflow had fewer trends during the more recent analysis period of WYs 1980-2013 than WYs 1945-2013 for all streamgages in eastern South Dakota. Upward trends in residuals for MarchMay mean streamflow were indicated for Skunk Creek at Sioux Falls and the Big Sioux River at Akron, but trends in residuals were not significant at the remaining streamgages.

For the streamgages with significant trends in residual streamflow (such as the streamgage on the Whetstone River and streamgages in the Big Sioux River Basin), land-use changes likely are minor factors, with the main factors probably being changes in the timing and frequency of large precipitation events and persistently wetter antecedent conditions. Changes in the relation between precipitation and streamflow since 1945 were evident when considering the runoff efficiency of the watershed. For example, the streamflow response to annual precipitation of 25 inches for the James River near Scotland increased from approximately 1,000 cubic feet per second for WYs 1945-1990 to about 2,500 cubic feet per second for WYs 1991-2013. The importance of antecedent conditions on annual mean streamflow also was indicated by the significance of the multiple linear regression coefficients of annual mean streamflow and precipitation from preceding water years for all but one streamgage. In addition, rising groundwater levels are present in wells in eastern South Dakota, particularly since the 1980s.

\section{Introduction}

Across the conterminous United States, precipitation has increased by 10 percent since 1910, reflecting an increase in both the frequency of days with precipitation and the magnitude of extreme precipitation events (Karl and Knight, 1998). Anderson and Woosley (2005) observed an increasing precipitation gradient across the Missouri River Basin with downward precipitation trends since 1971 for more arid States such as Montana, Wyoming, western North Dakota, and western and southern Nebraska and upward trends in South Dakota, southeast North Dakota, and northeast Nebraska. Precipitation increased as much as 25 percent in the eastern Great Plains and decreased as much as 15 percent in the western Great Plains from 1958 to 2008 (Karl and others, 2009). Walsh and others (2014) indicated the amount of precipitation from very heavy rainfall events (1-percent exceedance rate) increased by 16 to 37 percent since 1958 for the north-central United States.

Continental-scale and regional-scale trends also have been identified in observed surface air temperature. Surface air temperature in the United States has had an upward trend on the order of 2 degrees Fahrenheit $\left({ }^{\circ} \mathrm{F}\right)$ since records began in 1895, with most of the increase since the 1970s (Walsh and others, 2014). Evidence for climate warming also is evident in the Missouri River Basin. Mean surface air temperature for 1993-2008 in the Missouri River Basin was 1 to $3^{\circ} \mathrm{F}$ warmer than the mean for 1961-79, with greatest warming in the northern part of the basin (Karl and others, 2009).

Trends in streamflow have been examined by several researchers at national and regional scales (Slack and Landwehr, 1992; Dettinger and Cayan, 1995; Lins and Slack, 1999; McCabe and Wolock, 2002; Dettinger, 2005; Lins, 2005). Anderson and Woosley (2005) noted an apparent, but not statistically significant, upward streamflow trend for the Missouri River during 1950-2000. Hirsch and Ryberg (2011) reported significant trends of decreasing peak flows for streamgages with at least 85 years of continuous record through water year (WY) 2008 in the northwestern United States, which included parts of the Missouri River Basin; a WY is the 12-month period, October 1 through September 30, and is designated by the calendar year in which it ends. Norton and others (2014) examined annual and seasonal trends in streamflow at 227 streamgages in the Missouri River Basin with records for WYs 1960-2011 and noted pronounced upward trends in annual streamflow at streamgages along the James and Big Sioux Rivers. Hirsch (2011) noted an anomalous and pronounced upward trend in annual minimum daily streamflow in the Big Sioux River at Akron, Iowa (streamgage 06485500, fig. 1). Coopersmith and others (2014) examined hydroclimate trends for 428 watersheds in the United States during 1948-2003. Watersheds within the Missouri River Basin were classified as having an arid climate with high seasonality in the western part of the basin and nonarid climate with high seasonality in the eastern part of the basin. Changes in the mechanism of runoff were indicated for the Midwest United States with the runoff peak shifting from early spring to early summer, and runoff associated with precipitation events rather than in response to thawing of the ground. Mallakpour and Villarini (2015) examined flood magnitudes and frequencies for 1962-2011 at streamgages in the central United States. Although their overarching conclusion was that evidence of significant changes in magnitude of peak streamflow events was limited, an increased frequency of streamflow events greater than a threshold was evident. Examination of their regional plots, however, indicated upward trends in frequency and magnitude of annual, spring, summer, and autumn peak streamflow events, and upward trends in winter peak streamflow events for the region considered for this study. Regional plots by Mallakpour and Villarini (2015) also indicated that an upward trend in the frequency and magnitude of heavy rainfall events was present in autumn in eastern South Dakota. Changes in peak streamflow events in South Dakota, North Dakota, and Iowa were attributed to changes in precipitation, air temperature, and associated snowpack (Mallakpour and Villarini, 2015; Pederson and others, 2011). Pronounced anomalies in several metrics of streamflow since about the 1980s have been recognized in this region, including the Big Sioux River (Hirsch, 2011; Norton and others, 2014; Ryberg and others, 2014). 


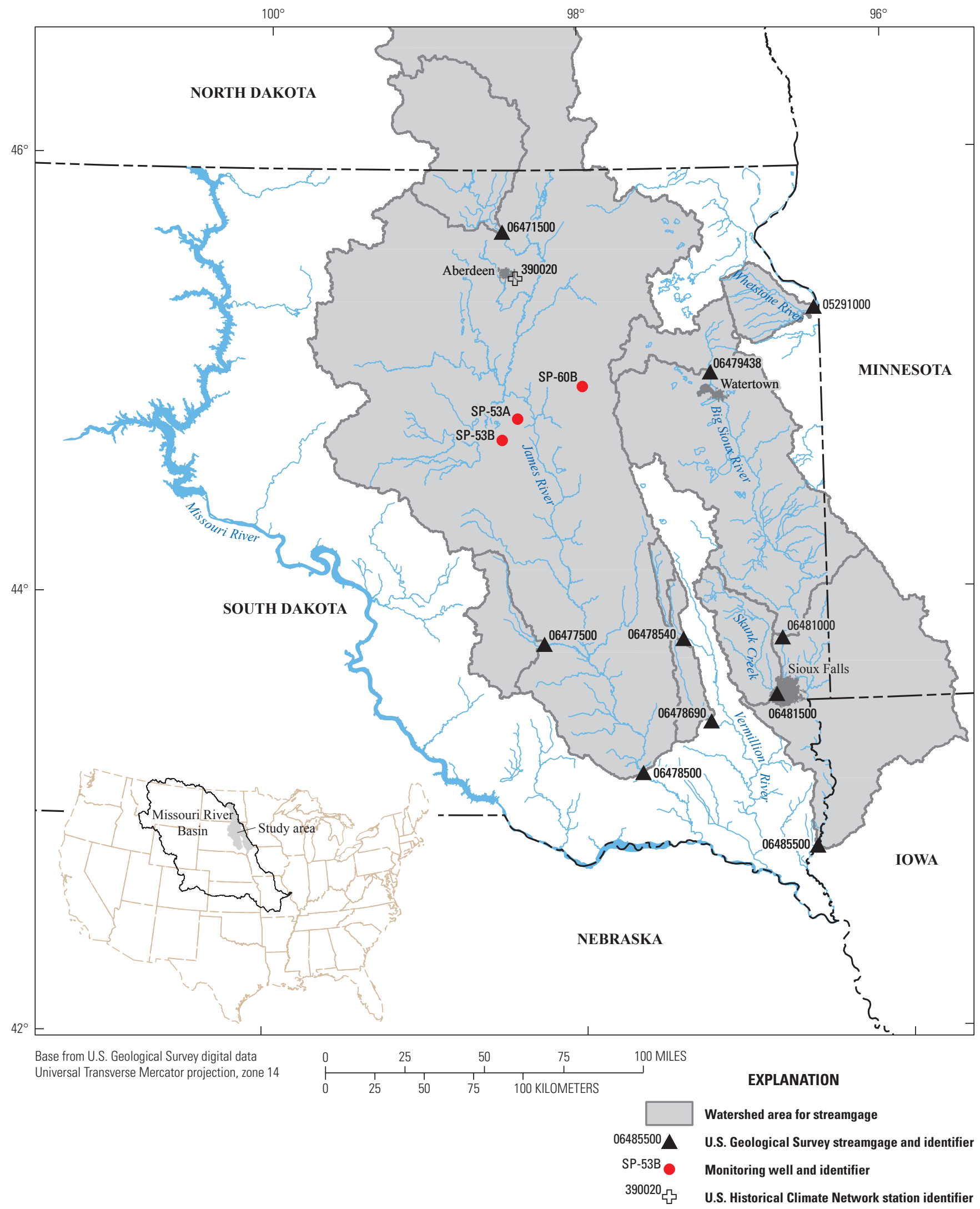

Figure 1. Study area and locations of 10 streamgages and their associated watersheds in James, Big Sioux, Vermillion, and Minnesota River Basins included in this study. 
Climate and Streamflow Characteristics for Selected Streamgages in Eastern South Dakota, Water Years 1945-2013

Forcing factors for streamflow trends in eastern South Dakota are not well understood, and it is not known whether streamflow trends are driven primarily by climatic changes or various land-use changes. Multiple land-use alterations with the potential for substantial effects on streamflow characteristics are known to have occurred since European settlement began in the 1860s. Some of these land-use alterations include (1) small- and large-scale drainage improvements over widespread, poorly drained areas, (2) conversion of massive tracts of native tall-grass prairie to farmland and rangeland, (3) large-scale changes over time in agricultural land use that have resulted from implementation of various U.S. Department of Agriculture farm programs such as the Conservation Reserve Program (CRP), and (4) urbanization. Pattern tiling, which is the practice of installing perforated pipe beneath agricultural fields to drain water and lower a shallow water table, is rapidly expanding in the midwestern States (Baker and others, 2007). The practice is in response to persistently wet climatic conditions and a period of high commodity prices, especially for corn. The CRP encourages farmers to convert highly erodible cropland or other environmentally sensitive acreage to vegetative cover (such as native grasslands) for the duration of a contract period; however, an increase in commodity prices may have contributed to the 27 -percent decrease in eastern South Dakota land enrolled in the CRP during 2007-10 (U.S. Department of Agriculture, 2012). The changes to streamflow characteristics of receiving streams resulting from these land-use changes are unknown. Understanding the effects that climate (specifically precipitation and temperature) has on streamflow characteristics within a region will help to better understand additional factors such as land-use alterations that may affect the hydrology of the region. Assessment of precipitation trends provides a local perspective on continental-scale and regional-scale studies of climate variability and trends. To aid in this understanding, a study was completed by the U.S. Geological Survey (USGS), in cooperation with the East Dakota Water Development District and James River Water Development District, to assess trends in climate and streamflow characteristics at 10 selected streamgages (fig. 1) in eastern South Dakota for WYs 1945-2013 (69 years) and WYs 1980-2013 (34 years). The assessment of precipitation trends also provides a local perspective on continental-scale and regional-scale studies of climate variability and trends.

\section{Purpose and Scope}

This report provides an assessment of the relations among trends in climate characteristics (precipitation and air temperature) and trends in streamflow characteristics at selected streamgages in eastern South Dakota for WYs 1945-2013. Climate and streamflow characteristics were assessed at 10 selected streamgages in eastern South Dakota for WYs 1945-2013 (69 years) and WYs 1980-2013 (34 years). One streamgage is on a tributary to the Minnesota River; the other streamgages are in the James, Big Sioux, and Vermillion River
Basins in the Missouri River Basin. The watersheds for two of the James River streamgages extend into North Dakota, and parts of the watersheds for two of the Big Sioux River streamgages extend into Minnesota and Iowa (fig. 1). This report documents (1) trends in streamflow, precipitation, and air temperature in eastern South Dakota; and (2) trend analyses of the precipitation-removed streamflow to characterize the streamflow variability that is caused by factors other than precipitation.

\section{Description of Study Area}

The James, Big Sioux, and Vermillion Rivers, and the Whetstone River, which is a tributary to the Minnesota River (fig. 1), are part of the Central Lowland physiographic division (not shown on fig. 1), which is characterized by glaciated terrain and rolling plains (Fenneman, 1931). Glacial units in the region include Quaternary-age till, outwash, and lacustrine sediments (Martin and others, 2004). Rivers commonly follow the valleys formed by glacial lobes, which were glaciated as recently as 14,000 years ago (Lundstrom and others, 2009). Drainages in this region formed after retreat of glaciers and are therefore poorly established in parts of the study area. The poorly established drainage patterns are accompanied by numerous areas of internal drainages, or "potholes," and are why the larger region surrounding the study area is commonly referred to as the "Prairie Pothole Region."

The estimated mean thickness of glacial deposits is 40 feet (ft) in eastern South Dakota, and locally the maximum thickness is as much as $500 \mathrm{ft}$ (Flint, 1955). Whitehead (1996) indicates that glacial deposits are the most productive aquifers in this region. Developed aquifers commonly are ancient stream channel deposits in valleys that have been buried beneath glacial till and typically are in areas of thickest glacial deposits (Whitehead, 1996). Where underlain by Cretaceousage shale, loss of groundwater from glacial aquifers to bedrock is minimized (Bredehoeft and others, 1983). The uppermost bedrock units in the watersheds in eastern South Dakota and in the watersheds that extend into North Dakota, Minnesota, and Iowa primarily are Cretaceous-age shales and sandstones (Tomhave and Schulz, 2004; Morey and Meints, 2000; Witzke and others, 2010). Precambrian-age rocks, such as diabase, quartzite, and granite, underlie glacial deposits in small areas in the southern parts of the watersheds included in this study and are locally exposed at the surface near Sioux Falls, South Dakota (Martin and others, 2004).

Agricultural activities are extensive throughout eastern South Dakota (fig. 2). The largest cities in the basin have developed along the James, Vermillion, and Big Sioux Rivers, and contribute urban runoff and wastewater effluent discharges to these rivers. About 66 percent of the area in study watersheds in the Big Sioux River Basin is used for cultivated crops (fig. 2C), and other agricultural activities in the basin include livestock and concentrated animal-feeding operations (Homer and others, 2015). Crops grown in the Big Sioux River Basin 

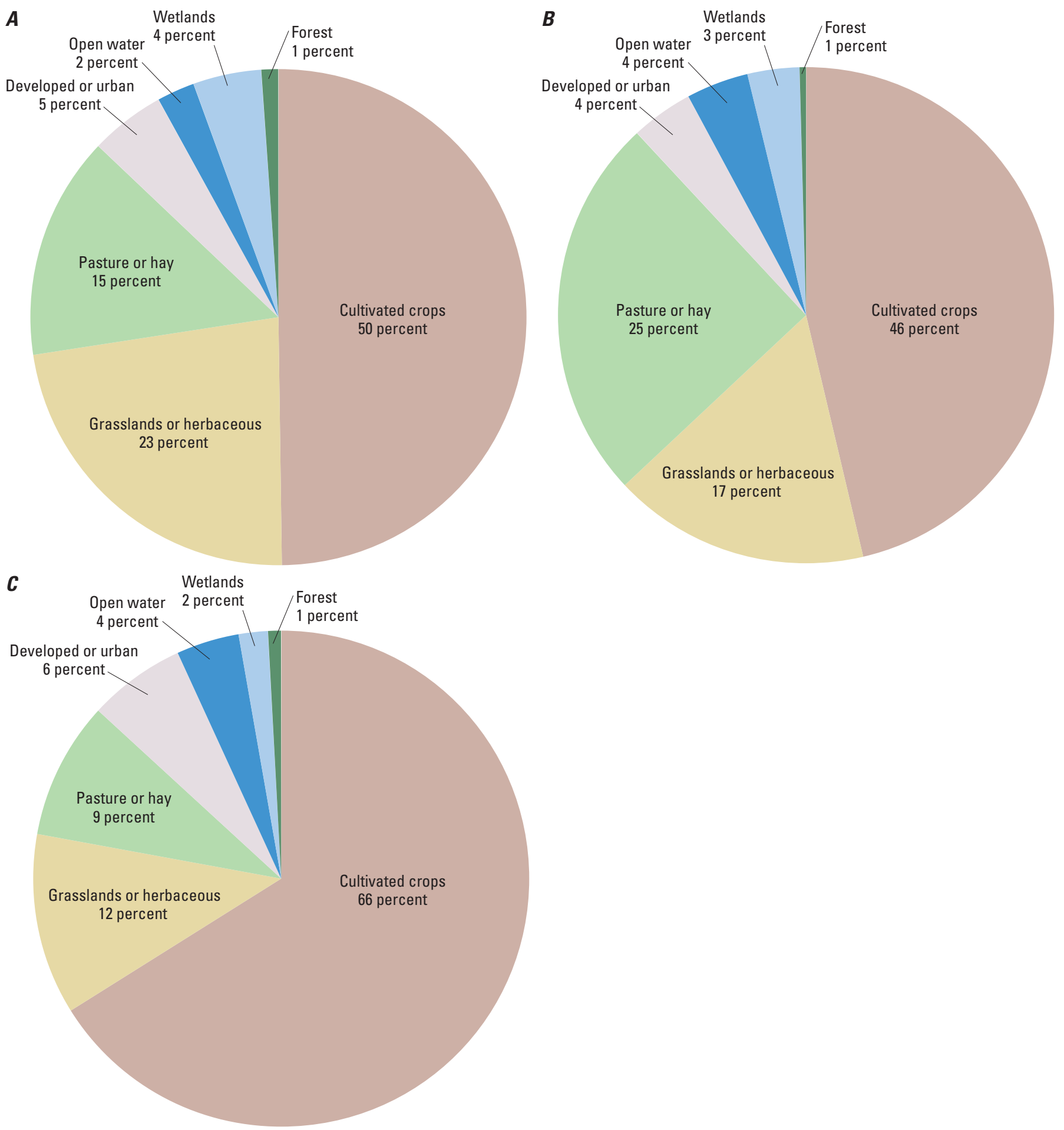

Figure 2. Land use in study watersheds (from Homer and others, 2015). $A$, Whetstone River watershed in the Minnesota River Basin. $B$, Watersheds in the James River Basin. C, Watersheds in the Big Sioux River Basin. 
predominantly include corn, soybeans, wheat, and alfalfa; livestock raised in the basin primarily include dairy cattle, beef cattle, and hogs (Lawrence and Sando, 1991). Landuse characteristics in the Whetstone River watershed in the Minnesota River Basin and in study watersheds in the James River Basin (fig. $2 A, \mathrm{~B}$ ) are similar to characteristics in the Big Sioux River Basin, although more pasture and grassland areas are present in these watersheds compared to watersheds in the Big Sioux River Basin.

The climate of the study area was characterized by using records for 1945-2013 for the Aberdeen Regional Airport weather station (station 390020, fig. 1) from the U.S. Historical Climate Network (USHCN; National Oceanic and Atmospheric Administration, 2015). Mean monthly precipitation is lowest in the winter and greatest in the summer (fig. 3), and has a unimodal distribution (rising to a single peak). Mean monthly precipitation at USHCN weather station 390020 for 1945-2013 ranged from 0.49 inch (in.) in December to 3.43 in. in June. Similarly, mean monthly air temperature is unimodal and is lowest in winter and highest in summer. Mean monthly air temperature ranges from $10.6^{\circ} \mathrm{F}$ in January to $72.1^{\circ} \mathrm{F}$ in July. Although precipitation is greater in June than other months, mean monthly streamflow is characteristically greatest in spring months of April and May as shown for the James River near Scotland, S. Dak. (streamgage 06478500), where the mean monthly streamflow for April was 2,570 cubic feet per second $\left(\mathrm{ft}^{3} / \mathrm{s}\right.$; fig. 3), which is nearly three times larger than mean annual streamflow of $906 \mathrm{ft}^{3} / \mathrm{s}$ (U.S. Geological Survey, 2014). April is the first month following winter that mean monthly air temperature rises above freezing (fig. 3); streamflows in April typically are augmented by snowmelt runoff. Saturated or frozen soil conditions in early spring also can contribute to increased runoff potential during spring rainfall events (Sando and others, 2008). Streamflow response to the greater precipitation of the summer months is subdued because of the greater evapotranspiration and generally drier soil conditions that are present during the growing season within the James River Basin and other basins in eastern South Dakota (Hay, 2012). Analyses presented herein will therefore include the relations between climate and streamflow for the 3-month March-May period associated with the rise, peak, and beginning of recession of streamflow in the typical annual hydrograph.

\section{Methods and Approach}

The methods and approach include the analysis of existing precipitation, air temperature, and streamflow data for watersheds in the study area. Watershed-scale precipitation and temperature data were calculated from the Parameter-Elevation Regressions on Independent Slopes Model (PRISM), which provides estimates of monthly precipitation and temperature at a 2.5 arc-minute grid spacing (Daly and others, 1994). The PRISM outputs of monthly precipitation, minimum
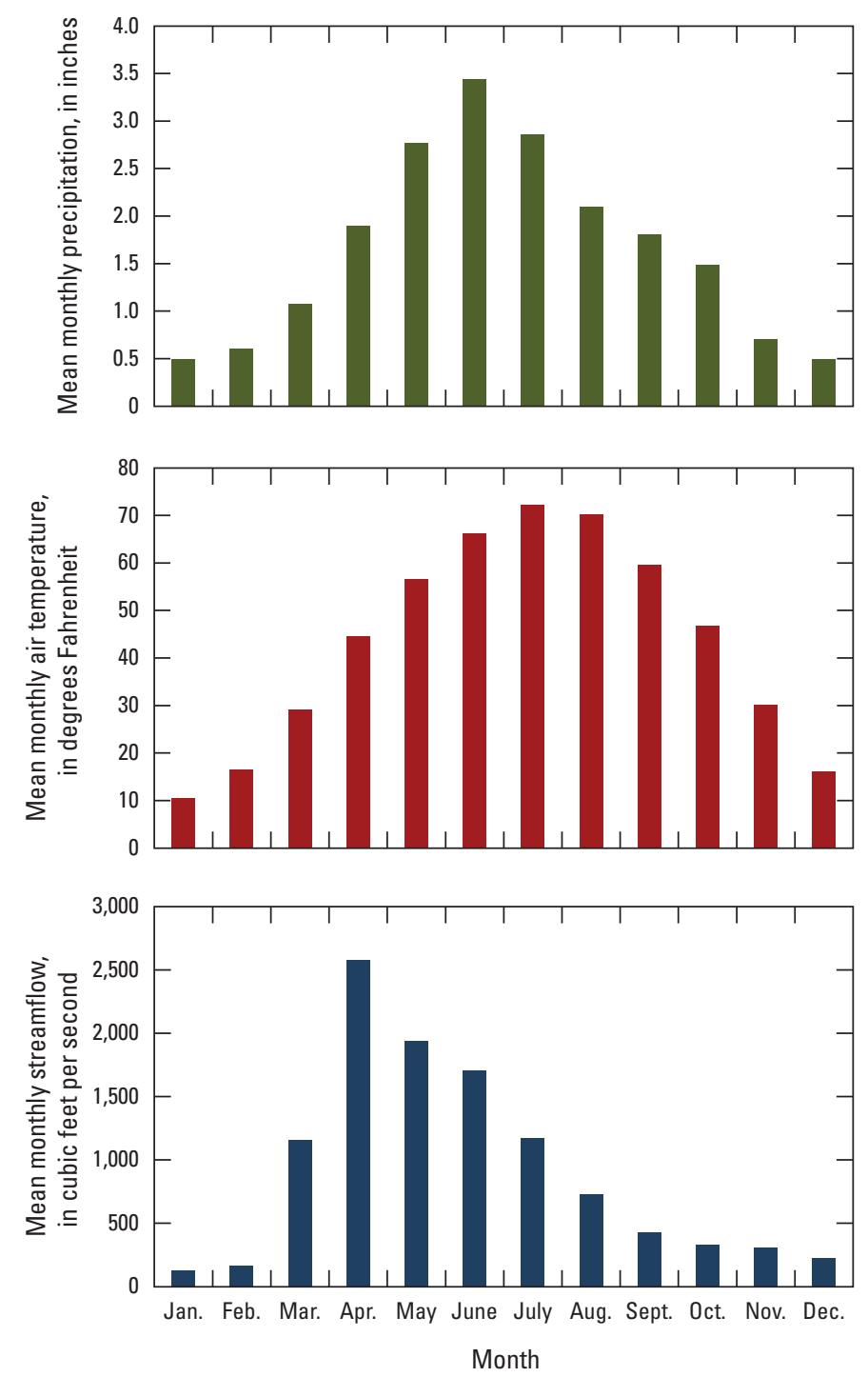

Figure 3. Mean monthly precipitation and air temperature at the Aberdeen Regional Airport Historical Climatology Network weather station (data from National Oceanic and Atmospheric Administration, 2015), and mean monthly streamflow at the James River near Scotland, South Dakota (streamgage 06478500; data from U.S. Geological Survey, 2014), calendar years 1945-2013.

air temperature, and maximum air temperature were spatially averaged for all grid points within each streamgage watershed. Streamflow data were obtained from the USGS National Water Information System (NWIS) (U.S. Geological Survey, 2014).

Streamgages that have long periods of record and include continuous data are most desirable for statistical analysis and interpretations of trends. Ten streamgages from four major river basins in eastern South Dakota were selected to represent a range of locations and contributing drainage areas (table 1). Sites generally were selected to represent upper and lower parts of the major river basins, with preference given to sites 
with at least 40 years of continuous record. For perspective on the magnitude of streamflows, the long-term mean annual streamflow for sites during the period of record ranged from $7.6 \mathrm{ft}^{3} / \mathrm{s}$ for the Little Vermillion River near Salem, S. Dak. (streamgage 06478540), to $1,530 \mathrm{ft}^{3} / \mathrm{s}$ for the Big Sioux River at Akron, Iowa (streamgage 06485500; table 1).

\section{Watershed Precipitation and Temperature}

The PRISM is a statistical model that interpolates monthly total precipitation and monthly means of daily maximum and minimum air temperature from weather station records to a 2.5 arc-minute grid that includes the conterminous United States (Daly and others, 1994, 2002, 2008). The statistical model is a knowledge-based system that interpolates data from multiple weather stations on the basis of similarity of the terrain at the weather stations with that of a given grid point. The PRISM output was validated for use in trend analyses in this region by comparison with records from the USHCN weather station 390020 (fig. 1). Validation methodologies included paired t-test (Helsel and Hirsch, 2002; Adler, 2010) to test for significant differences in population means, the Kendall-tau nonparametric test (Kendall, 1938; Helsel and Hirsch, 2002; Adler, 2010) for significance of correlation and trends, and the Kolmogorov-Smirnov nonparametric test (Adler, 2010) to determine if the distribution of USHCN data and PRISM output are similar. Nonparametric tests such as the Kendall tau and Kolmogorov-Smirnov tests do not assume a parameterized distribution. Water-resources data such as streamflow and precipitation characteristically violate the assumption of a normal distribution (Helsel and Hirsch, 2002), which might result from outliers or from data that are bounded - negative values of precipitation and streamflow are not possible.

\section{Statistical Analyses}

The statistical analyses provide a representative overview and interpretation of the streamflow and precipitation datasets. Streamflow values were summarized into four statistical groups for analyses by WY: (1) annual mean streamflow, (2) annual 7-day minimum streamflow, (3) mean daily streamflow for the March-May period, and (4) 7-day minimum streamflow for the March-May period. The March-May period was selected to represent the time when most flooding occurs in eastern South Dakota because of snowmelt or spring rain events. The 7-day minimum streamflow statistic (calculated as the minimum 7-day period of daily mean streamflow values) was selected to be representative of the base-flow condition for each year, independent of the short-term rainfall or snowmelt runoff processes. Streamflow trend tests were not conducted for the 7-day minimum streamflows at the Little Vermillion River near Salem, because this low-flow statistic was zero for greater than 25 percent of years. The beginning year of streamflow records for sites ranged from 1928 to 1972;

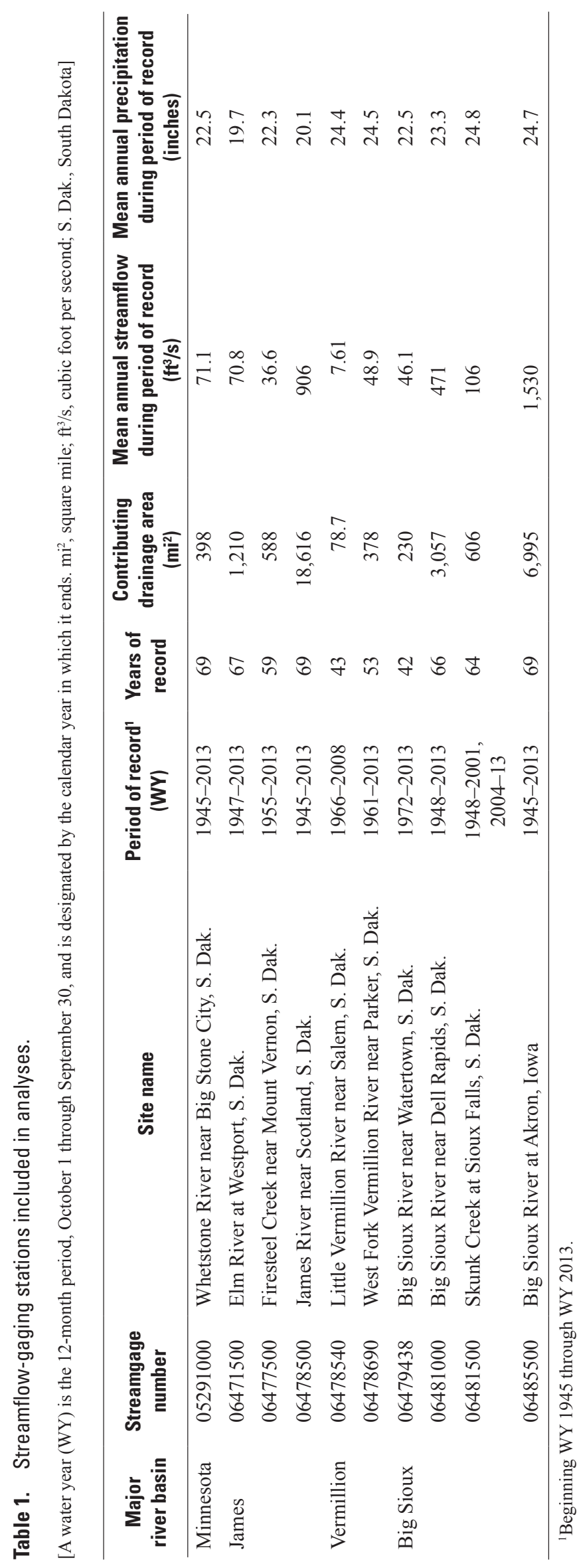


Climate and Streamflow Characteristics for Selected Streamgages in Eastern South Dakota, Water Years 1945-2013

this wide range poses a problem for comparison of monotonic trends among sites because there should be reasonable consistency in the datasets for strong comparisons. To alleviate this issue, two common periods of analysis were defined: WYs 1945-2013 and WYs 1980-2013. For the three streamgages with the shortest streamflow records (beginning after WY 1960), the longer 1945-2013 period was not considered in statistical analyses. This censoring was applied to streamflow records for the Little Vermillion River near Salem, West Fork Vermillion River near Parker, S. Dak. (streamgage 06478690), and Big Sioux River near Watertown, S. Dak. (streamgage 06479438), and allows for more representative comparison among sites. For example, at the Big Sioux River near Watertown, the longer period for WYs 1945-2013 would only include 8 additional years (record begins WY 1972), compared to the 35 possible additional years. Statistical analyses of precipitation and temperature were included for the WY 1945-2013 period for the watershed area for all streamgages because these records were not limited by record length. All of the streamflow statistics were obtained from the NWIS database using the Exploration and Graphics for RivEr Trends (EGRET) processing software (Hirsch and De Cicco, 2014), which is a package for the statistical computing software R ( R Core Team, 2014).

Monthly precipitation totals from PRISM output were summarized into four seasonal groups for analyses of trends; monthly mean temperatures were summarized into five seasonal groups for analyses of trends. Seasonal groups for precipitation included annual (by WY), March-May, September-November (spanning 2 water years), and December-May. The annual and March-May groups were selected to correspond with the two seasonal streamflow groups described previously in this section. The September-November season generally is not associated with substantial contribution of runoff to streams because precipitation commonly is consumed by evapotranspiration or accumulates as snowpack during these months; thus, increased moisture during this period primarily serves to saturate soils before the winter and spring seasons. The December-May period represents the combined precipitation from winter snow accumulation and the spring rainfall period leading up to the months of greatest streamflow in eastern South Dakota (April and May, fig. 3). The air temperature seasons investigated for trends include annual (by WY) and four 3-month periods that approximate the solar seasons: January-March, April-June, July-September, and OctoberDecember. Because air temperature in eastern South Dakota follows a more uniform seasonal pattern (fig. 3) compared to the precipitation and streamflow patterns, the four solar seasons were selected for investigation of trends instead of those used in the streamflow and precipitation statistical analyses.

Precipitation and streamflow data are not normally distributed and often have outliers that affect parametric tests; therefore, a nonparametric Mann-Kendall approach was used. The Mann-Kendall test (Helsel and Hirsch, 2002) was used to examine precipitation, air temperature, and streamflow for monotonic increases (upward trend) or decreases (downward trend) with time. A monotonic upward or downward trend is one in which the change in the variable of interest consistently increases (upward trend) or decreases (downward trend) through time, but the trend may or may not be linear. The null hypothesis of the Mann-Kendall test is that the probability of variable $Y$ at time $j\left(Y_{j}\right)$ being greater than $Y$ at time $i\left(Y_{i}\right)$, where $j$ is greater than $i$, is 0.5 (50 percent chance of an increase in time). The alternative hypothesis is that the probability of $Y_{j}$ being greater than $Y_{i}$ is something other than 0.5 (if it is greater than $0.5, Y$ is tending to increase with time; if it is less than $0.5, Y$ is tending to decrease with time). Statistical tests used in this study all used a significance level equal to 0.10 (a $p$-value less than 0.10 means the test is statistically significant). To examine the magnitude of changes identified by the Mann-Kendall test, the Sen slope estimate (Theil, 1950; Sen, 1968) is reported with each $p$-value. The Sen slope estimate is the median of all pairwise slopes in the dataset, presented in units of cubic feet per second per year, inches per year, or degrees Fahrenheit per year for streamflow, precipitation, or air temperature trends, respectively. The utility of Sen slope estimates for a time-series plot of annual mean streamflow for the James River near Scotland, is shown in figure 4 . The trendlines shown in figure 4 project a line with the Sen slope through the point representing the median time and median streamflow value. In this example, the annual mean streamflow increases at a median rate of 10.5 cubic feet per second per year $\left(\left[\mathrm{ft}^{3} / \mathrm{s}\right] / \mathrm{yr}\right)$ during WYs 1945-2013 and increases at a median rate of $30.0\left(\mathrm{ft}^{3} / \mathrm{s}\right) / \mathrm{yr}$ during WYs 1980-2013.

Helsel and Hirsch (2002) describe a methodology of removing the variability from an associated exogenous variable known to affect the dependent variable tested for time trends. Exogenous variables are usually natural, random phenomena such as precipitation or air temperature, and herein the dependent variable is streamflow. By removing the variation in streamflow explained by precipitation, the background variability or "noise" is reduced so that any residual trend present can be identified, which allows focus on variables that affect streamflow but are not associated with precipitation. Thomas and Pool (2006) and Ryberg and others (2014) provide recent example applications of this method to factor out climatic variability of streamflow. The first step was to develop locallyweighed scatterplot smoothing (LOWESS) relations between precipitation and streamflow using all years in the record. The residuals from the regression analysis represent streamflow values that have had the variation caused by precipitation removed and are termed "precipitation-removed streamflow." The second step was to test for monotonic trends in the residuals over time using a Mann-Kendall test. Trends, if present in these residuals, can then be attributed to factors other than precipitation.

In LOWESS, a different weighted least-squares regression is used to compute each fitted value. The weights for each equation are a function of a user-specified span and the magnitude of the residual from the previous regression. The span specifies the number of data points that are used to fit 


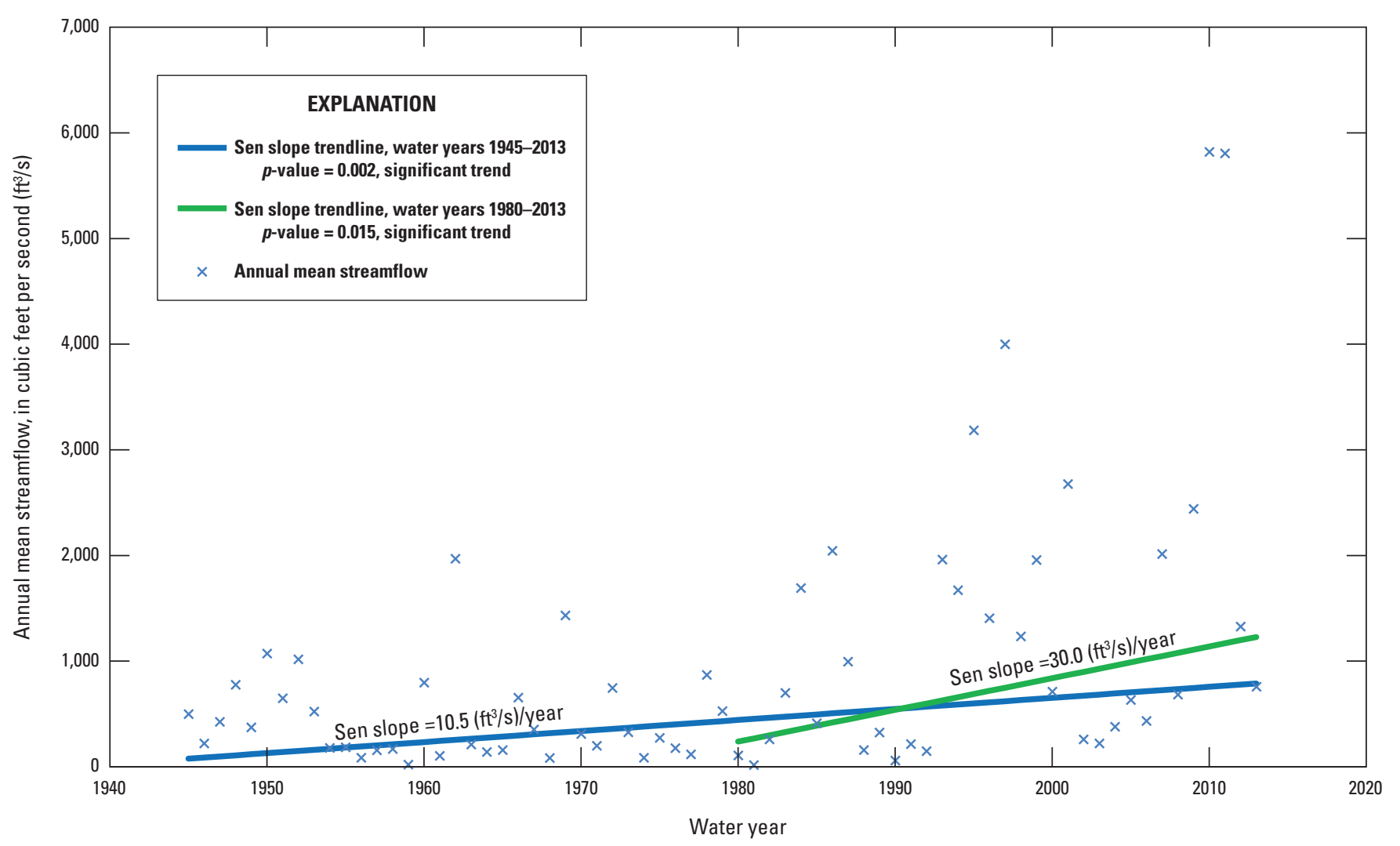

Figure 4. Annual mean streamflow and Sen slope trendlines for James River near Scotland, South Dakota (streamgage 06478500), water years 1945-2013.

the equation. A larger span will, therefore, have a smoother fitted model than a smaller span. A span of 0.50 indicates that 50 percent of the data are used to fit each equation, which was the default span used in this analysis. The effect of using alternative spans of 0.35 and 0.65 also was examined at one streamgage, which resulted in similar significance levels in the residual trend tests (no test went from significant to non-significant or vice versa with the use of these alternative spans). After development, the LOWESS relations were evaluated for applicability using coefficients of determination $\left(R^{2}\right)$, which measure the goodness of fit by the precipitation-based LOWESS model (Ott and Longnecker, 2001). The $R^{2}$ values were calculated in a similar way as utilized in typical linear regression models, where the correlation coefficient between the dependent streamflow variable and LOWESS streamflow value is squared:

where

$$
R^{2}=\left(\frac{\sum(x-\bar{x})(y-\bar{y})}{\sqrt{ }\left(\sum(x-\bar{x})^{2} \sum(y-\bar{y})^{2}\right)}\right)^{2}
$$

$x$ is the actual streamflow statistic,

$y \quad$ is the corresponding LOWESS model value of streamflow for the same year, and

$\bar{x}$ and $\bar{y} \quad$ are the respective mean values of these data.
Multiple linear regression methods were used to examine the significance of precipitation from previous years on streamflow statistics. In this approach, multiple previous years of precipitation can be used to account for the observed streamflow in any given year. This is in contrast with the LOWESS models described in the previous paragraph, which only use the precipitation from the current year to describe the streamflow. The multiple regression model relates the dependent variable (a streamflow statistic) to a set of independent variables (precipitation) using a direct extension of a polynomial regression model in one independent variable (Ott and Longnecker, 2001). The precipitation independent variables include the current WY precipitation, the previous WY precipitation (WY-1), and the precipitation from 2 WYs before the current WY (WY-2). The goal of the regression analysis is to explain as much as possible of the variation observed in the streamflow, leaving as little variation as possible in the unexplained portion (Helsel and Hirsch, 2002). The t-test was performed for the coefficient for each preceding water year's precipitation in the multiple linear regression models, and $p$-values are reported, thereby statistically characterizing the relative importance of antecedent precipitation when explaining streamflow. This tests whether a more complex model (with the additional year of precipitation) provides a sufficiently better explanation of the variation in streamflow than 
does the simpler model that uses only the current year's precipitation (Helsel and Hirsch, 2002). Assumptions of multiple linear regression models were verified, including checks that explanatory variables are independent (no multicollinearity) and residuals were normally distributed (Helsel and Hirsch, 2002).

\section{Validation of Output from the Parameter- Elevation Regression on Independent Slopes Model}

Gibson and others (2002) and McCabe and Wolock (2011) indicate that PRISM output preceding 1950 may not be suitable for temporal trend analyses due to sparseness of weather station records and on the basis of models of streamflow computed using PRISM output. Suitability of PRISM output for a region can be estimated by comparison of weather station records with PRISM output. Records of annual precipitation at USHCN station 390020 for 1928-2013 (National Oceanic and Atmospheric Administration, 2015) compared to that computed from PRISM output for the associated grid point (latitude $44.4433^{\circ} \mathrm{N}$, longitude $98.4131^{\circ} \mathrm{W}$ ) was used to validate the use of PRISM output (fig. 5) for this study. The
Kolmogorov-Smirnov test indicates no significant difference between the distribution of USHCN records and PRISM output.

Mann-Kendall tests for trends in precipitation during 1928-2013 indicated a significant upward trend ( $p$-value of 0.01 ) for PRISM output but no significant trend ( $p$-value of 0.11 ) for USHCN records. Similarly, Mann-Kendall tests for trends in precipitation for 1940-2013 indicated a significant upward trend for PRISM output and no significant trend for USHCN records, which indicates higher uncertainty in the interpretation of PRISM output for the period beginning before 1940. The Mann-Kendall tests indicated significant upward trends for PRISM output and USHCN records for 1945-2013, 1950-2013, and 1960-2013; therefore, PRISM output for 1945-2013 is considered valid for use in this study. The validity of using PRISM precipitation data during this period is illustrated in figure 5, as data points plot reasonably close to and are approximately normally distributed about the line of equal precipitation, and heteroscedasticity is not indicated. The truncation of records beginning in WY 1945 for analyses affects 3 of the 10 streamgages with the longest records (table 1): Whetstone River near Big Stone City, S. Dak. (streamgage 05291000); James River near Scotland; and Big Sioux River at Akron.

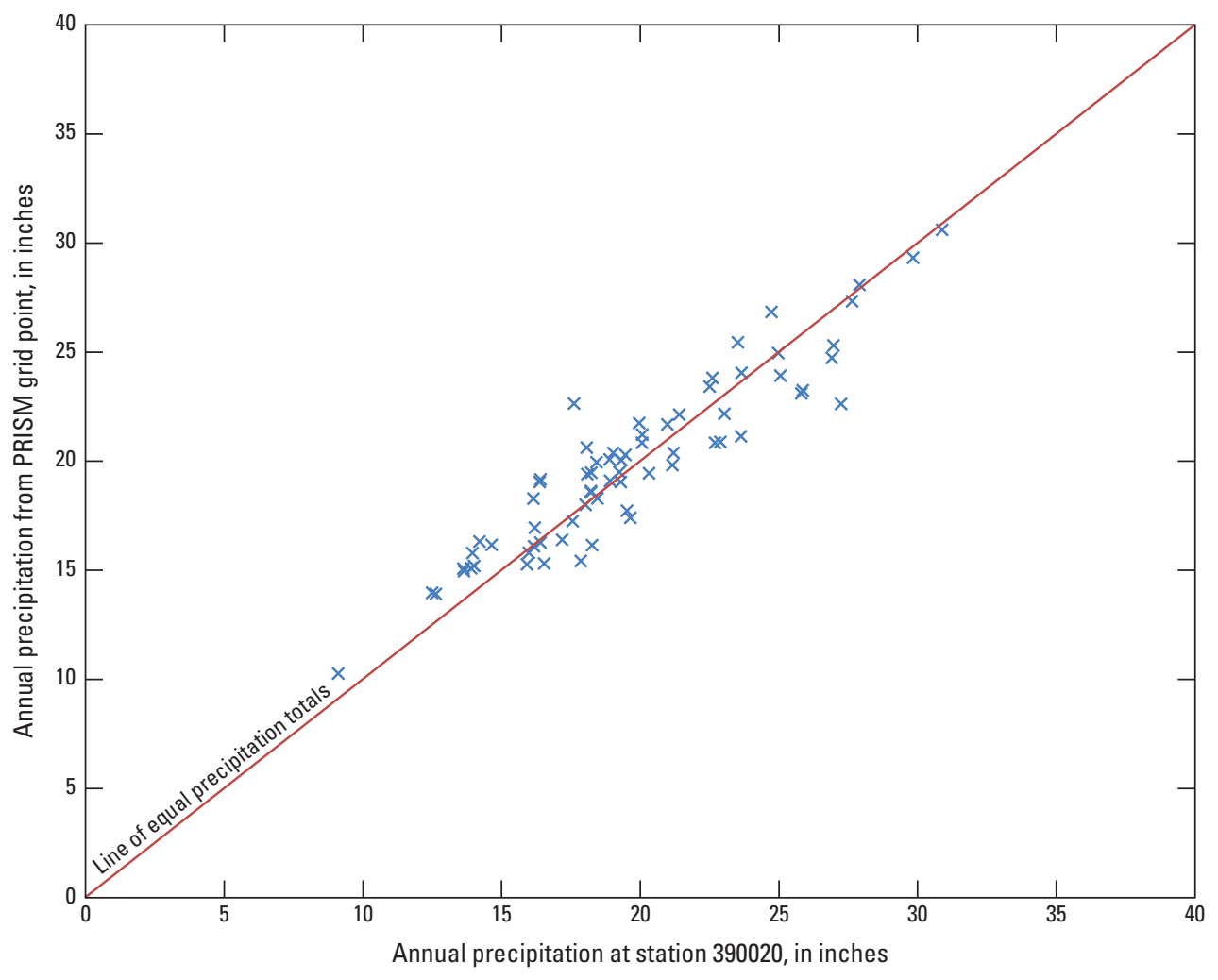

Figure 5. Relation between annual total precipitation at the Aberdeen Regional Airport (U.S. Historical Climatology Network weather station 390020) and the Parameter-Elevation Regression on Independent Slopes Model (PRISM) output for the grid point at the same location, 1945-2013. 


\section{Climate and Streamflow Characteristics}

Statistical analyses were completed for the 10 selected streamgages to determine the significance ( $p$-values) and magnitude (Sen slope) of trends in streamflow, precipitation, air temperature, and precipitation-removed streamflow (tables 2-4). Unless otherwise noted, all trends for these variables were upward when present. Plots for the three streamgages with the longest records-Whetstone River near Big Stone City; James River near Scotland; and Big Sioux River at Akron - are presented to show temporal streamflow patterns. Trendlines showing the 10 -year moving average (decadal mean) are presented with all time-series plots to assist with identification of hydrological changes over time. Streamflow and precipitation data used in these analyses are presented in the appendix.

\section{Streamflow Trends}

The upward trends in annual and seasonal streamflow documented by Norton and others (2014) are widespread across eastern South Dakota (table 2). Annual and March-May changes by WY in mean and 7-day minimum streamflow during WYs 1945-2013 are shown in figures 6 and 7, respectively, for the Whetstone River near Big Stone City; James River near Scotland; and Big Sioux River at Akron. Of the 10 streamgages selected for analyses in this study, only the Elm River at Westport, S. Dak. (streamgage 06471500), did not have a significant upward trend in annual mean streamflow for WYs 1945-2013 (table 2). Reservoirs with regulated releases account for about 40 percent of the headwater drainage area above the Elm River at Westport, which explains the lack of a streamflow trend at this site. All streamgages had upward trends in annual 7-day minimum streamflow during this period. The magnitude of trends in annual mean streamflow (characterized by Sen slopes) ranged from $0.269\left(\mathrm{ft}^{3} / \mathrm{s}\right) / \mathrm{yr}$ at Firesteel Creek near Mount Vernon, S. Dak. (streamgage 06477500) to $10.5\left(\mathrm{ft}^{3} / \mathrm{s}\right) / \mathrm{yr}$ at James River near Scotland. These trend slopes are similar relative to the long-term mean annual streamflow (table 1) at these two streamgages; the trend slope of $0.269\left(\mathrm{ft}^{3} / \mathrm{s}\right) / \mathrm{yr}$ represents 0.73 percent of the long-term streamflow value of $36.6 \mathrm{ft}^{3} / \mathrm{s}$ for Firesteel Creek near Mount Vernon, whereas the trend slope of $10.5\left(\mathrm{ft}^{3} / \mathrm{s}\right) / \mathrm{yr}$ represents 1.2 percent of the long-term streamflow value of $906 \mathrm{ft}^{3} / \mathrm{s}$ for the James River near Scotland.

Only one-half of the streamgages had significant upward trends in annual mean streamflow for the WY 1980-2013 period, which might be a result of (1) fewer data points than necessary to express a trend, (2) a wetter starting period than in 1945, or (3) more stability of non-climatic factors (such as land use). Trend slopes were greater, however, during WYs 1980-2013 than during WYs 1945-2013. For the James River near Scotland, the annual mean streamflow trend slope of $30.0\left(\mathrm{ft}^{3} / \mathrm{s}\right) / \mathrm{yr}$ during WYs $1980-2013$ was three times greater than trend slope of $10.5\left(\mathrm{ft}^{3} / \mathrm{s}\right) / \mathrm{yr}$ during WYs 1945-2013 (table 2).

Mean and 7-day minimum streamflows also had an upward trend for the spring runoff period (March-May) at most streamgages during WYs 1945-2013 (fig. 7, table 2). The only streamgages that had significant upward trends for March-May during WYs 1980-2013 were the James River near Scotland for the 7-day minimum streamflow (fig. 7B) and the Big Sioux River near Watertown for mean streamflow. The upward trend in the March-May 7-day minimum streamflow for the James River near Scotland had a magnitude of 5.29 $\left(\mathrm{ft}^{3} / \mathrm{s}\right) / \mathrm{yr}$ during WYs 1980-2013, which is 0.58 percent of the long-term mean annual flow of $906 \mathrm{ft}^{3} / \mathrm{s}$ (table 1); this is the greatest increase in 7-day minimum streamflow relative to long-term annual mean streamflow. The upward trend in March-May mean streamflow for the Big Sioux River near Watertown had a magnitude of $1.93\left(\mathrm{ft}^{3} / \mathrm{s}\right) / \mathrm{yr}$ during WYs 1980-2013, which is 4.2 percent of the long-term mean annual flow of $46.1 \mathrm{ft}^{3} / \mathrm{s}$; for all streamflow trends identified, this is the greatest increase relative to long-term mean annual streamflow. In summary, more upward streamflow trends are present across eastern South Dakota during the WY 1945-2013 period than during the WY 1980-2013 period; however, when trends are present, streamflow increases at a greater rate during the WY 1980-2013 period.

\section{Precipitation Trends}

Significant precipitation trends during WYs 1945-2013 are less prevalent than streamflow trends in eastern South Dakota watersheds. Annual precipitation (totaled by WY) had a significant upward trend for the watersheds of 4 of the 10 streamgages during WYs 1945-2013 (table 3, fig. 8), but no significant trends in annual total precipitation were indicated for WYs 1980-2013. Evidence of change was identified during the seasons March-May, September-November, and December-May. Three watersheds had significant upward trends for March-May total precipitation for WYs 1945-2013, and two different watersheds had upward trends for MarchMay total precipitation for WYs 1980-2013. Evidence of increasing precipitation during the winter and spring months is indicated by significant upward trends in December-May total precipitation for six watersheds during WYs 1980-2013. Only three watersheds had significant upward trends in December-May total precipitation in WYs 1945-2013. The greatest magnitude of increase in precipitation was for the DecemberMay season during WYs 1980-2013, which had Sen slopes averaging 0.106 inch per year (in/yr) for the six watersheds with significant trends (table 3 ). Sen slopes for annual and March-May total precipitation were less than $0.075 \mathrm{in} / \mathrm{yr}$ for the watersheds of streamgages with significant trends.

The most widespread increase in seasonal total precipitation was indicated for the months of September-November, with significant trends indicated for the watersheds of 8 of the 


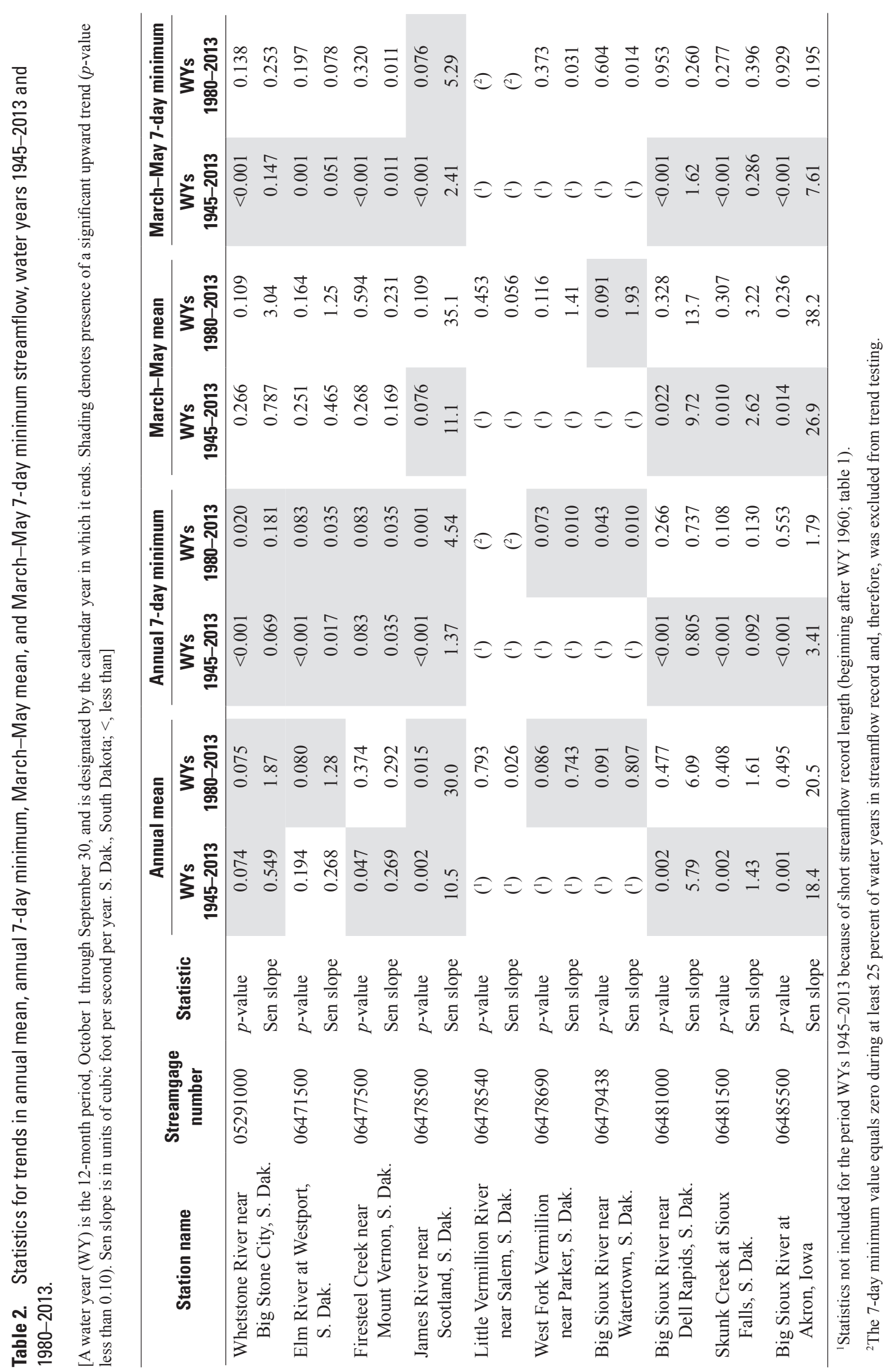



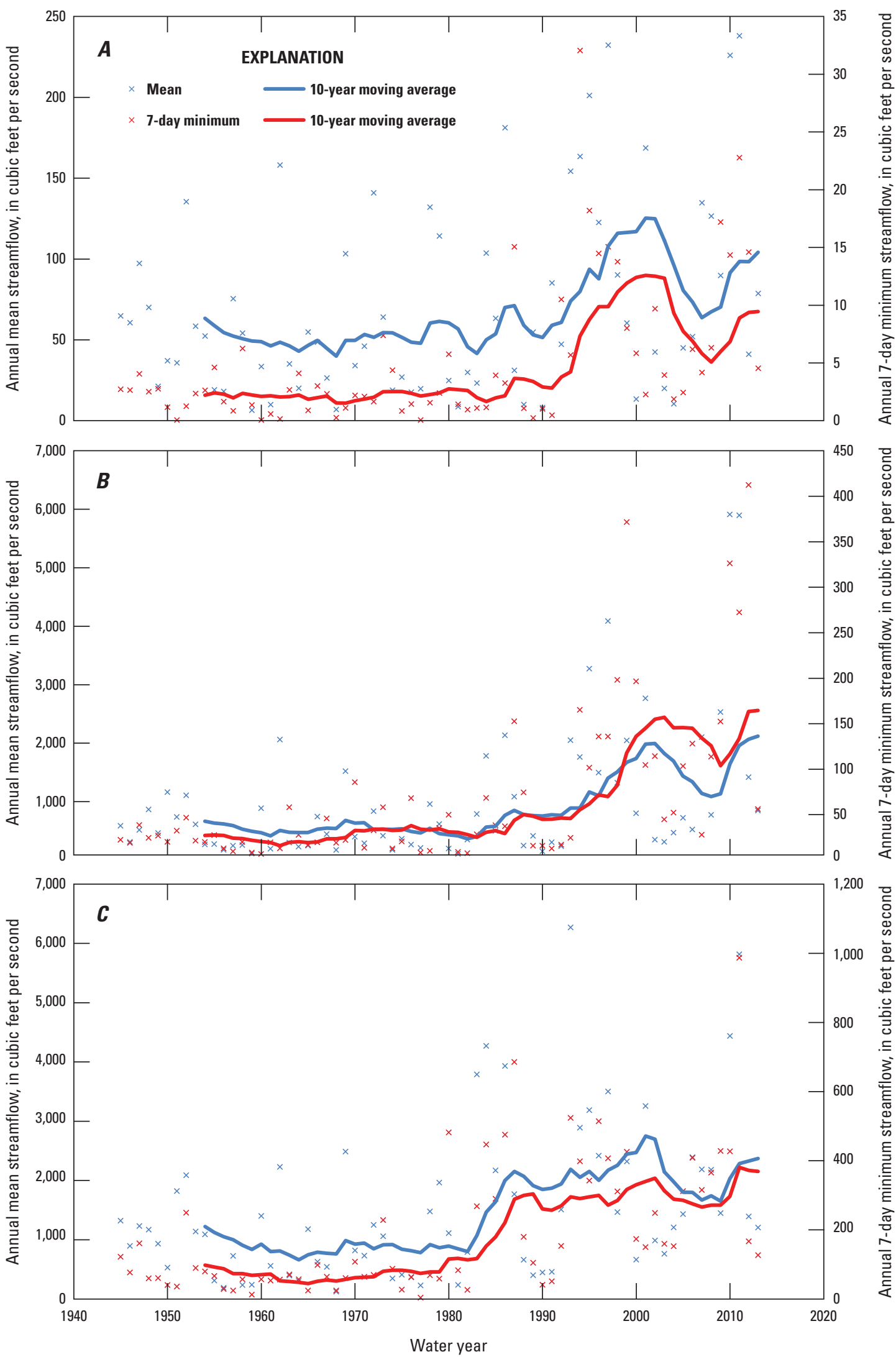

Figure 6. Annual mean and 7-day minimum streamflow for selected streamgages, water years 1945-2013. A, Whetstone River near Big Stone City, South Dakota (streamgage 05291000). B, James River near Scotland, South Dakota (streamgage 06478500). C, Big Sioux River at Akron, lowa (streamgage 06485500). 

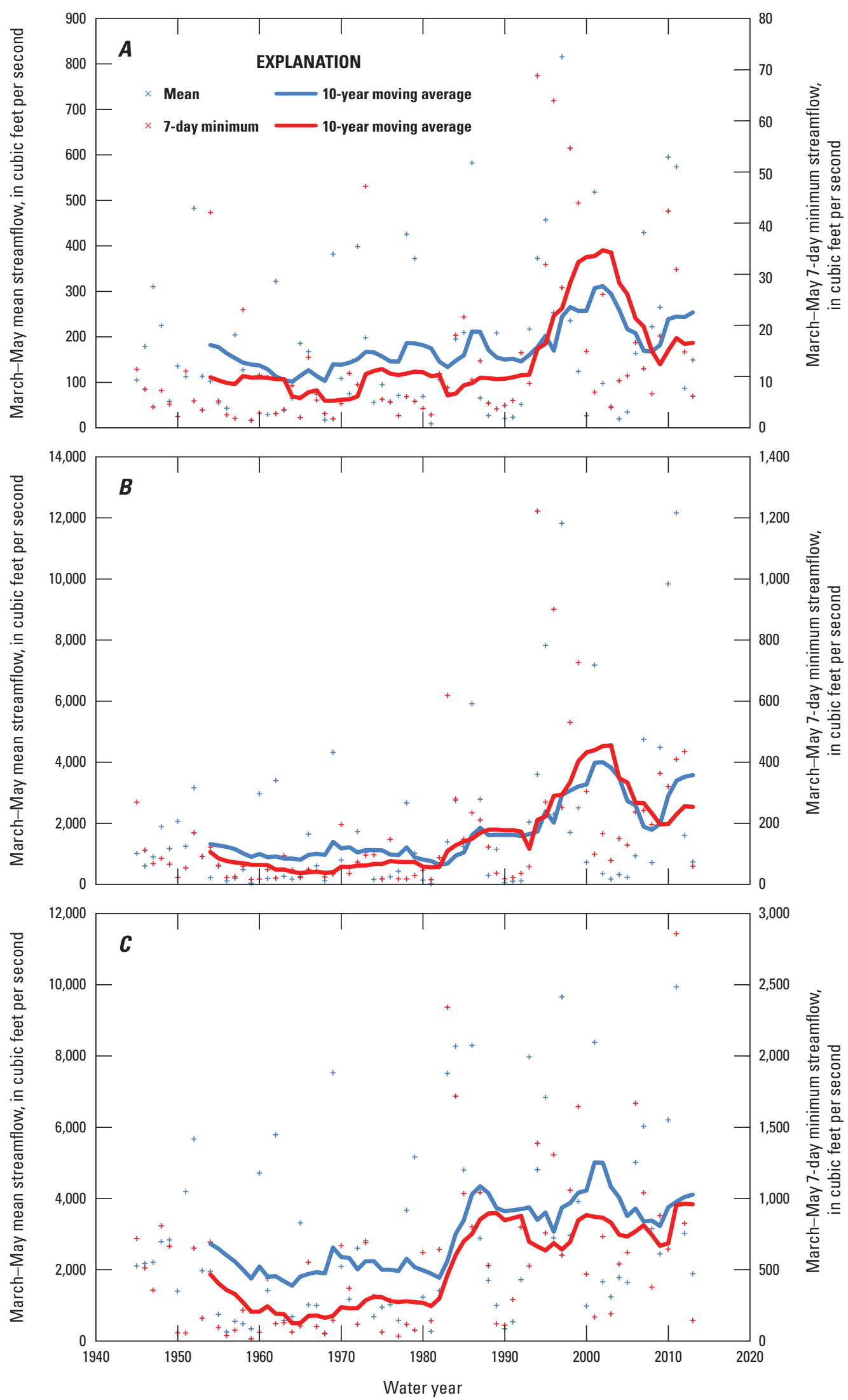

Figure 7. March-May mean and 7-day minimum streamflow for selected streamgages, water years 1945-2013. A, Whetstone River near Big Stone City, South Dakota (streamgage 05291000). B, James River near Scotland, South Dakota (streamgage 06478500). C, Big Sioux River at Akron, lowa (streamgage 06485500). 


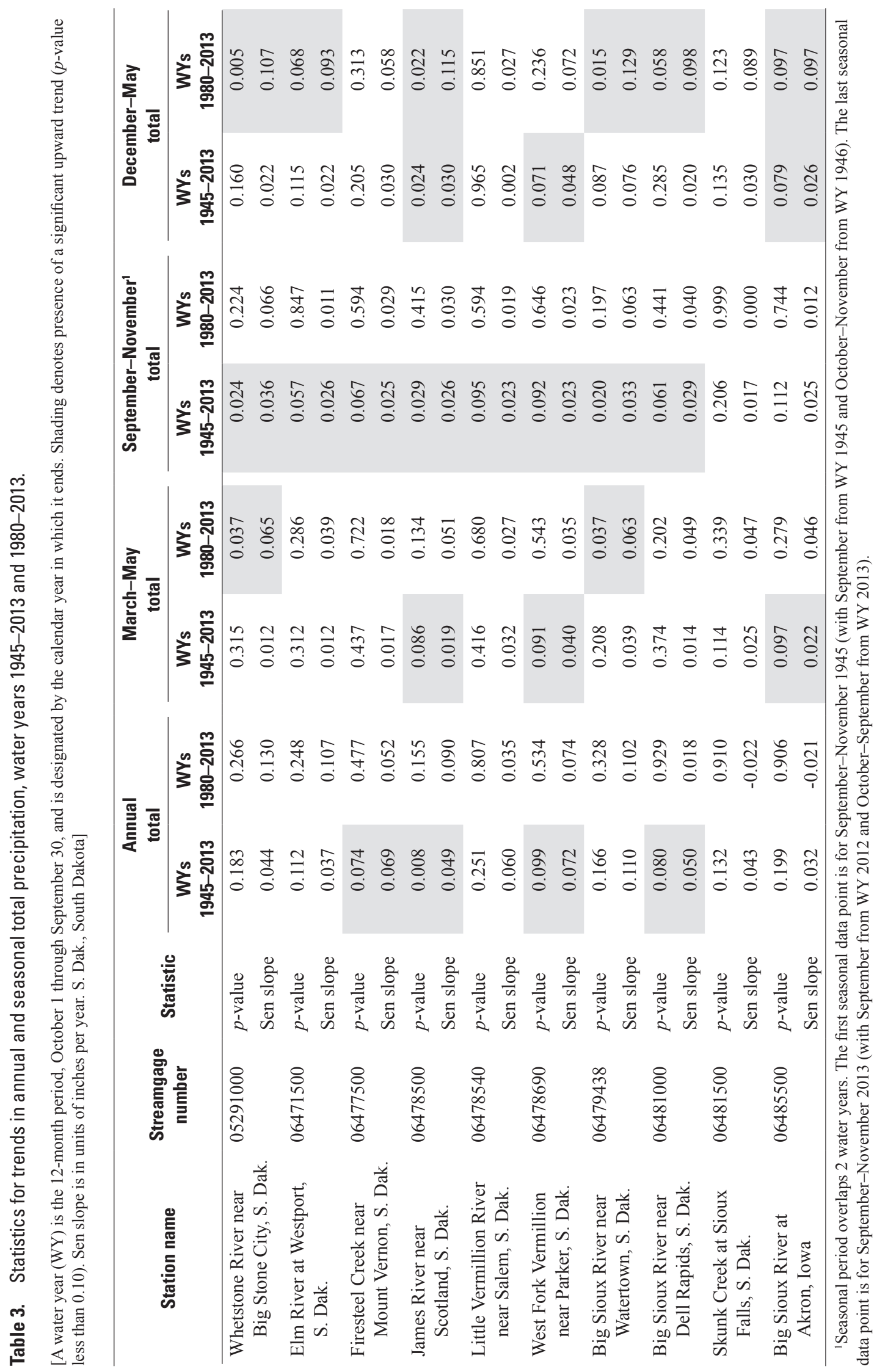



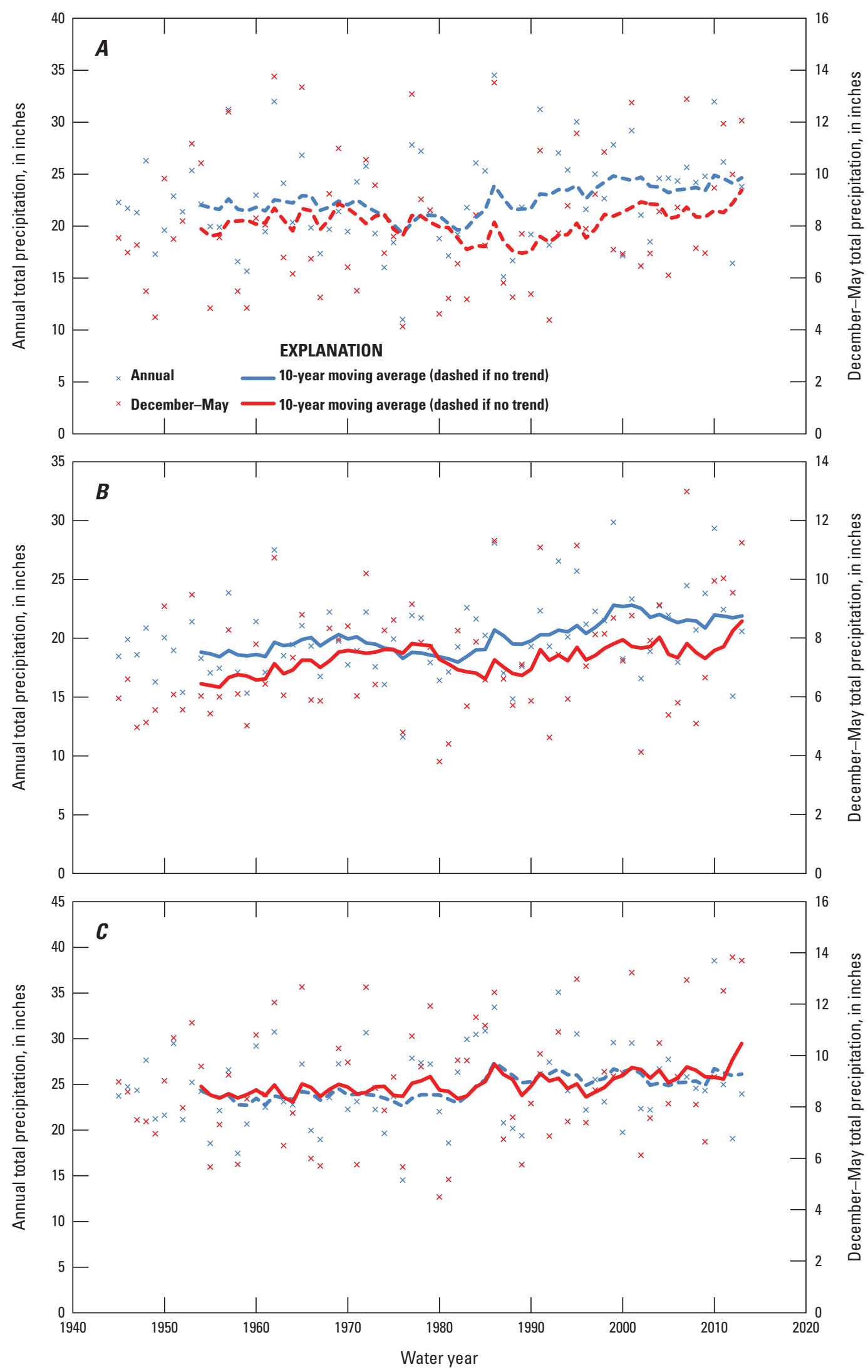

Figure 8. Total precipitation for watersheds of selected streamgages, water years 1945-2013. A, Whetstone River near Big Stone City, South Dakota (streamgage 05291000). B, James River near Scotland, South Dakota (streamgage 06478500). C, Big Sioux River at Akron, lowa (streamgage 06485500). The 10 -year moving average (decadal mean) is dashed when the trend is not significant according to the Kendall tau test at the 0.1 significance level. 
10 streamgages during WYs 1945-2013; however, no trends in September-November total precipitation were significant for WYs 1980-2013. Trend magnitudes for the SeptemberNovember season were low, averaging only $0.028 \mathrm{in} / \mathrm{yr}$. The watersheds for two streamgages - James River near Scotland and West Fork Vermillion River near Parker-had significant upward trends in all precipitation seasons (annual, MarchMay, September-November, and December-May) during WYs 1945-2013. Conversely, Skunk Creek at Sioux Falls, S. Dak. (streamgage 06481500) has a stationary precipitation record during all the seasons investigated (no significant trends indicated) and during both time periods evaluated. In summary, significant upward trends in total precipitation are indicated most strongly for the September-November season during the WY 1945-2013 period and for the December-May season during the WY 1980-2013 period; precipitation is relatively stable for all other seasons.

\section{Air Temperature Trends}

Air temperature changes were investigated for the watersheds of the streamgages on the James River near Scotland, Big Sioux River at Akron, and Whetstone River near Big Stone City (fig. 9), to further describe climatic variables that may affect streamflow. Temperature patterns are more consistent than streamflow patterns across eastern South Dakota; therefore, these three watersheds are likely representative of the region. Air temperature is an important driver of evapotranspiration; thus, warm temperatures typically translate into less water available for surface runoff during the summer and fall seasons. Conversely, warm temperatures in the winter and spring months increase snowmelt and can cause increased runoff during these periods.

Trends by WY in annual and seasonal means (OctoberDecember, January-March, April-June, July-September) were investigated. Air temperature trends were investigated for means of monthly maximum and minimum air temperatures in degrees Fahrenheit. With the exception of one downward trend in the July-September season for the Big Sioux River at Akron, no trends in maximum temperatures were identified for WYs 1945-2013 (table 4). Minimum air temperatures had significant upward annual and seasonal trends, except for the October-December season, in all three watersheds in WYs 1945-2013. The minimum temperature increased at a mean slope of $0.034^{\circ} \mathrm{F}$ per year. Few air temperature trends were identified for WYs 1980-2013; the significant trends were upward in July-September minimum air temperature and downward in April-June maximum air temperature. Although minimum air temperatures are increasing, the small magnitude of these upward trends and the downward (or stationary) trends in maximum temperature likely minimize any substantial changes to the evaporation or snowmelt regime of eastern South Dakota.

\section{Trends in Precipitation-Removed Streamflow}

This section describes the trend tests of the residuals remaining after removal of the streamflow variations that can be explained by precipitation. The LOWESS fit of streamflow metrics as a function of precipitation metrics is shown in figure 10 for the streamgages on the Whetsone River near Big Stone City, S. Dak.; James River near Scotland, S. Dak.; and Big Sioux River at Akron, Iowa.

The LOWESS streamflow-precipitation models were evaluated for goodness of fit using $R^{2}$, which provides a measure of the correlation between the observed streamflow statistic and LOWESS model values. The greatest $R^{2}$ values of the 12 streamflow-precipitation combinations (fig. 10) investigated were for regressions between annual mean streamflow and total precipitation (mean $R^{2}$ value of 0.47 ) and was as high as 0.72 for one streamgage (table 5). Regressed base flow as a function of precipitation (those involving 7-day minimum streamflows) had the poorest $R^{2}$ values, typically less than 0.10 (explaining less than 10 percent of the variation). The LOWESS regressions with poor $R^{2}$ values may not be useful in the second step, testing for trends of residuals, because the precipitation variable has little effect on the streamflow; therefore, only the precipitation-streamflow regressions with a mean LOWESS model $R^{2}$ value greater than 0.30 were included in the residual trend testing in this analysis. This criterion limited the precipitation-streamflow regressions used in analyses to two (table 6): (1) annual precipitation and annual mean streamflow (mean $R^{2}=0.47$, table 5), and (2) annual precipitation and MarchMay mean streamflow (mean $R^{2}=0.33$, table 5).

Changes in the relation between precipitation and streamflow in eastern South Dakota since WY 1945 are evident when considering the runoff efficiency (the amount of runoff that is generated for a given amount of precipitation) of the watershed. The LOWESS models relating WY precipitation and annual mean streamflow for three different periods (WYs 1945-67, WYs 1968-90, and WYs 1991-2013) are shown in figure 11. For annual total precipitation greater than about 20 in., the associated annual mean streamflow is much greater in the WY 1991-2013 period than the two earlier periods. For example, for an annual total precipitation of 25 in., the expected streamflow at the James River near Scotland increases from about $1,000 \mathrm{ft}^{3} / \mathrm{s}$ during both early periods (preceding WY 1991) to about 2,500 $\mathrm{ft}^{3} / \mathrm{s}$ in the most recent period (WYs 1991-2013) (fig. 11B).

Statistics ( $p$-values and Sen slopes) for trends in precipitation-removed streamflow are presented in table 6 , and timeseries plots of the precipitation-removed streamflow are shown in figure 12. Precipitation-removed streamflow refers to the residuals of the LOWESS relations (fig. 10) and is interpreted by the following: a significant trend ( $p$-value less than 0.10 ) in the precipitation-removed streamflow indicates that factors other than precipitation are important drivers of streamflow, and conversely, non-significant trends ( $p$-value equal to or greater than 0.10 ) indicate that precipitation explains most of the streamflow variability. 

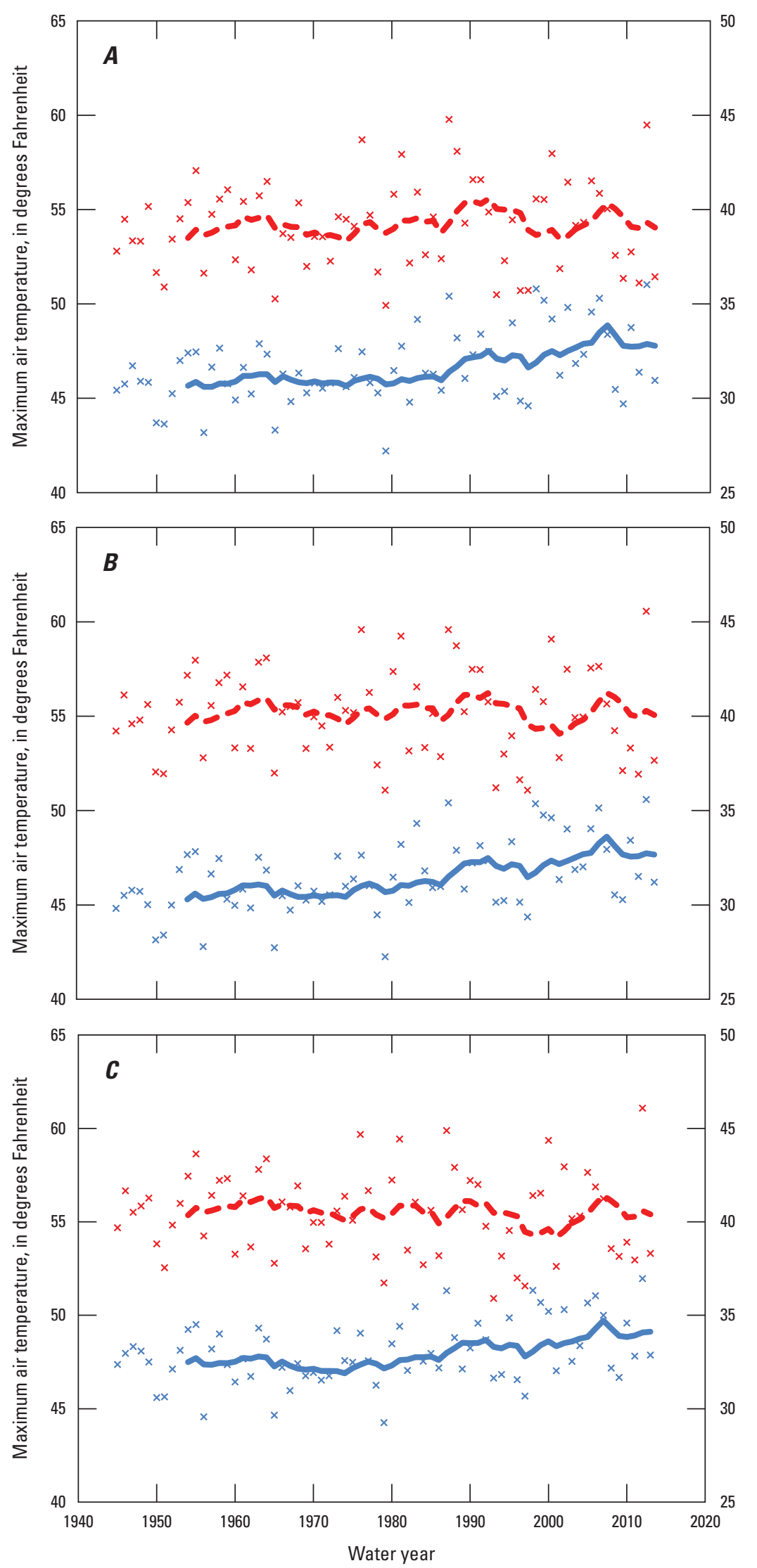

EXPLANATION

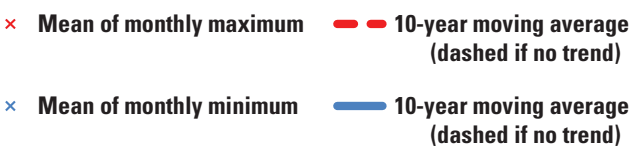
(dashed if no trend)
Figure 9. Mean of monthly maximum and minimum air temperature for watersheds of selected streamgages, water years 1945-2013. $A$, Whetstone River near Big Stone City, South Dakota (streamgage 05291000). B, James River near Scotland, South Dakota (streamgage 06478500). C, Big Sioux River at Akron, lowa (streamgage 06485500). The 10-year moving average (decadal mean) is dashed when the trend is not significant according to the Kendall tau test at the 0.1 significance level. 


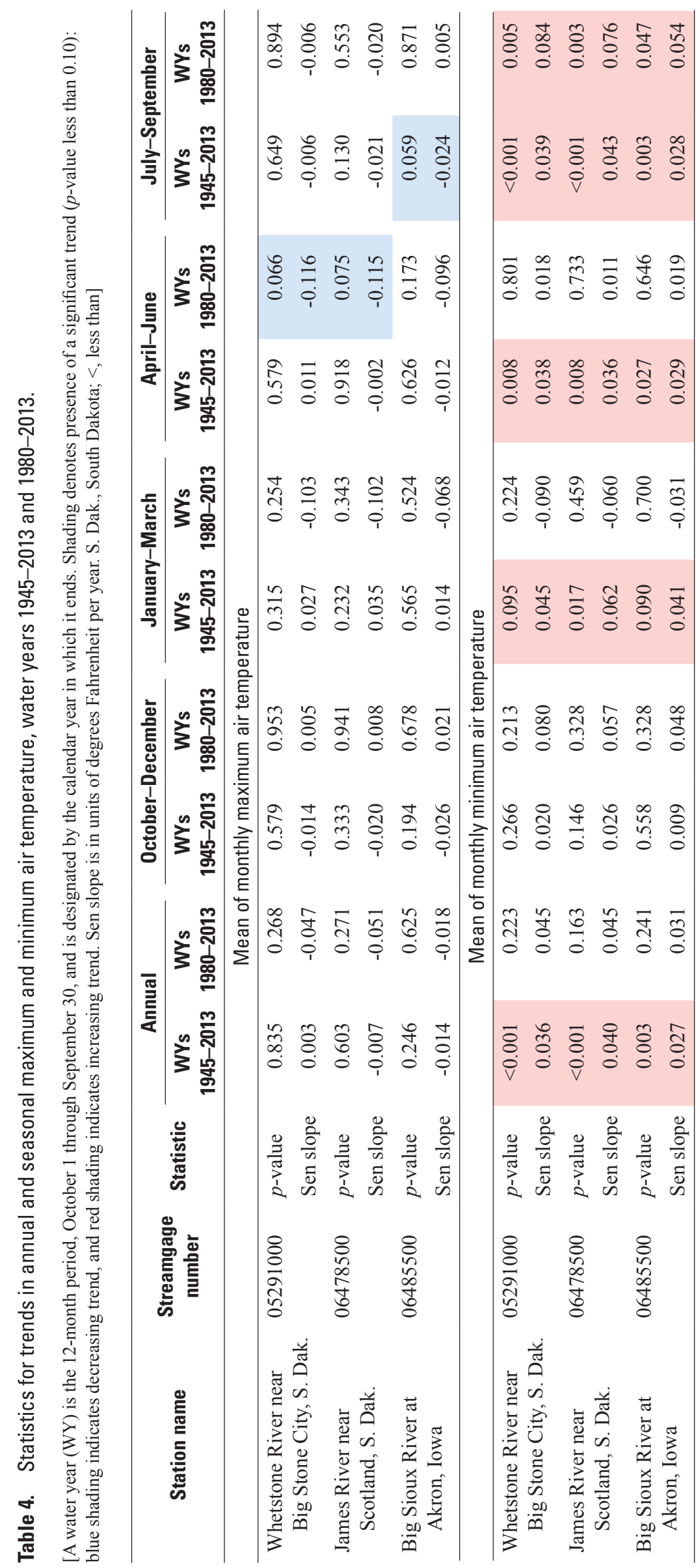


A
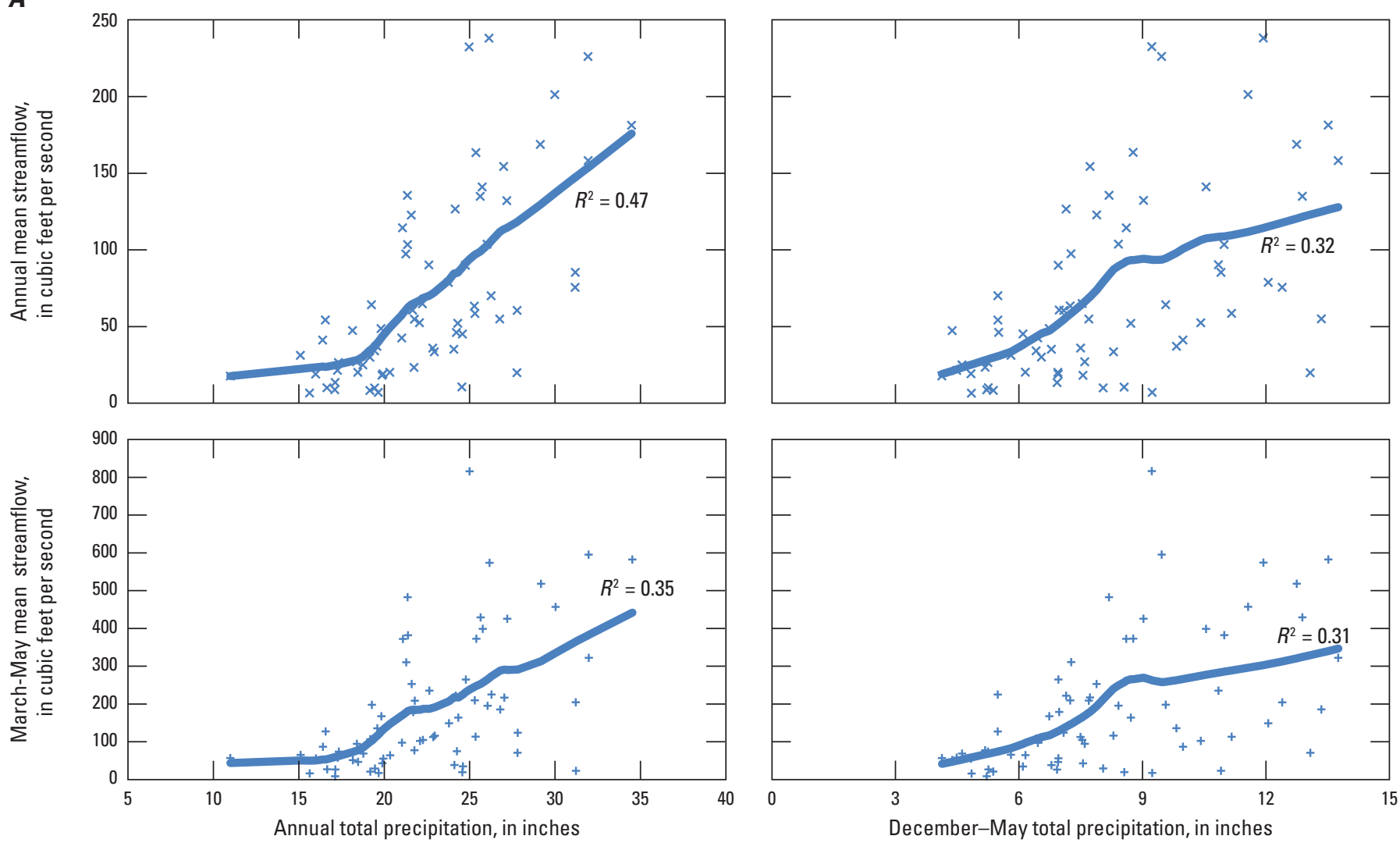

EXPLANATION

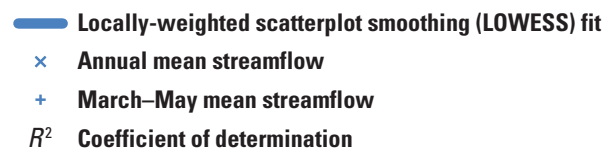

Figure 10. Relation between mean streamflow and total precipitation for annual and seasonal periods at selected streamgages, water years 1945-2013. A, Whetstone River near Big Stone City, South Dakota (streamgage 05291000). B, James River near Scotland, South Dakota (streamgage 06478500). C, Big Sioux River at Akron, lowa (streamgage 06485500). 
$\boldsymbol{B}$
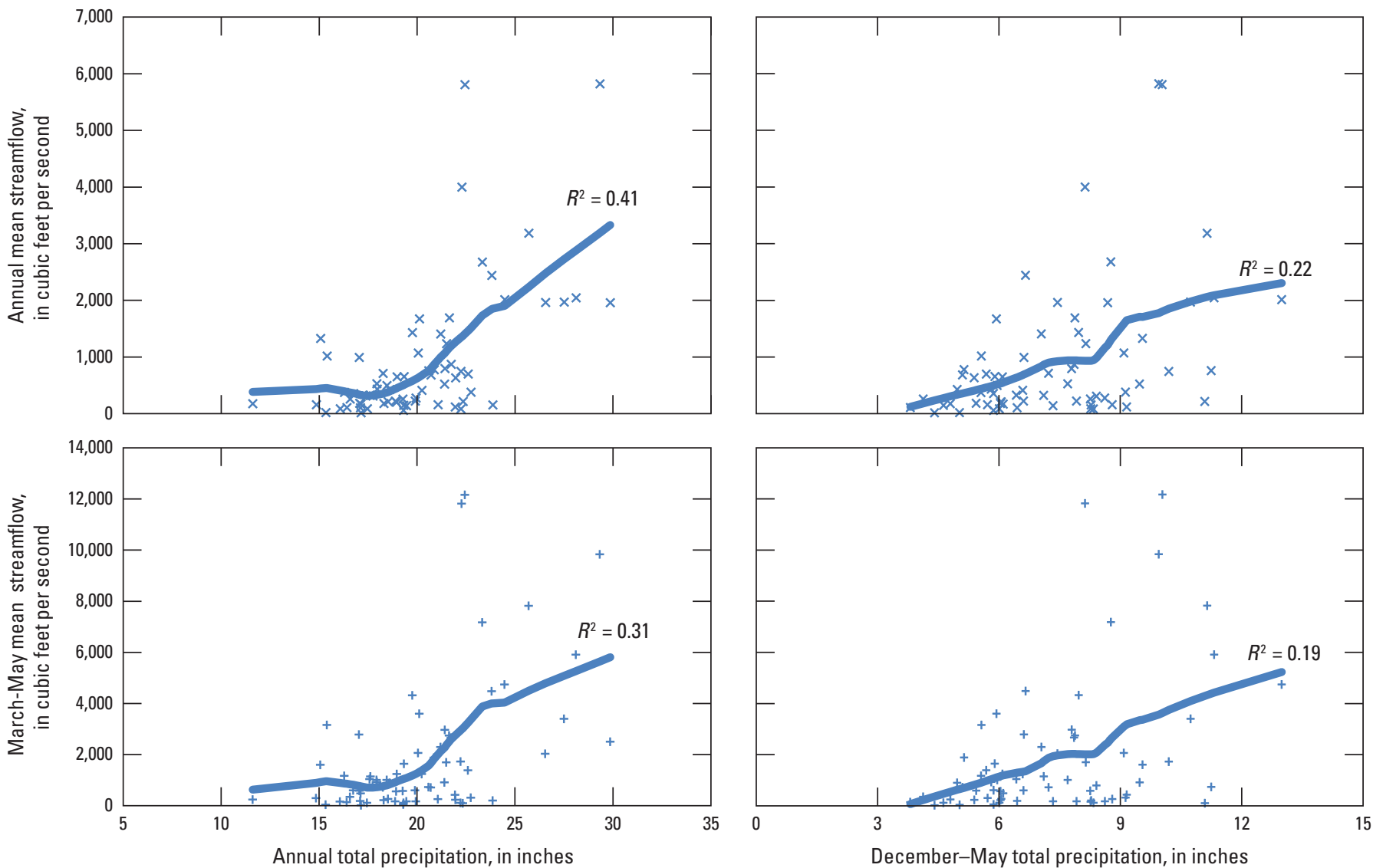

EXPLANATION

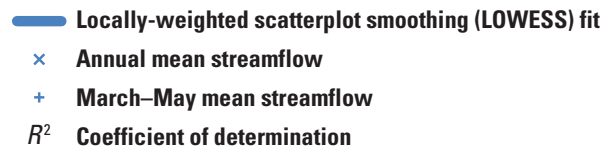

Figure 10. Relation between mean streamflow and total precipitation for annual and seasonal periods at selected streamgages, water years 1945-2013. A, Whetstone River near Big Stone City, South Dakota (streamgage 05291000). B, James River near Scotland, South Dakota (streamgage 06478500). C, Big Sioux River at Akron, lowa (streamgage 06485500).-Continued 
C
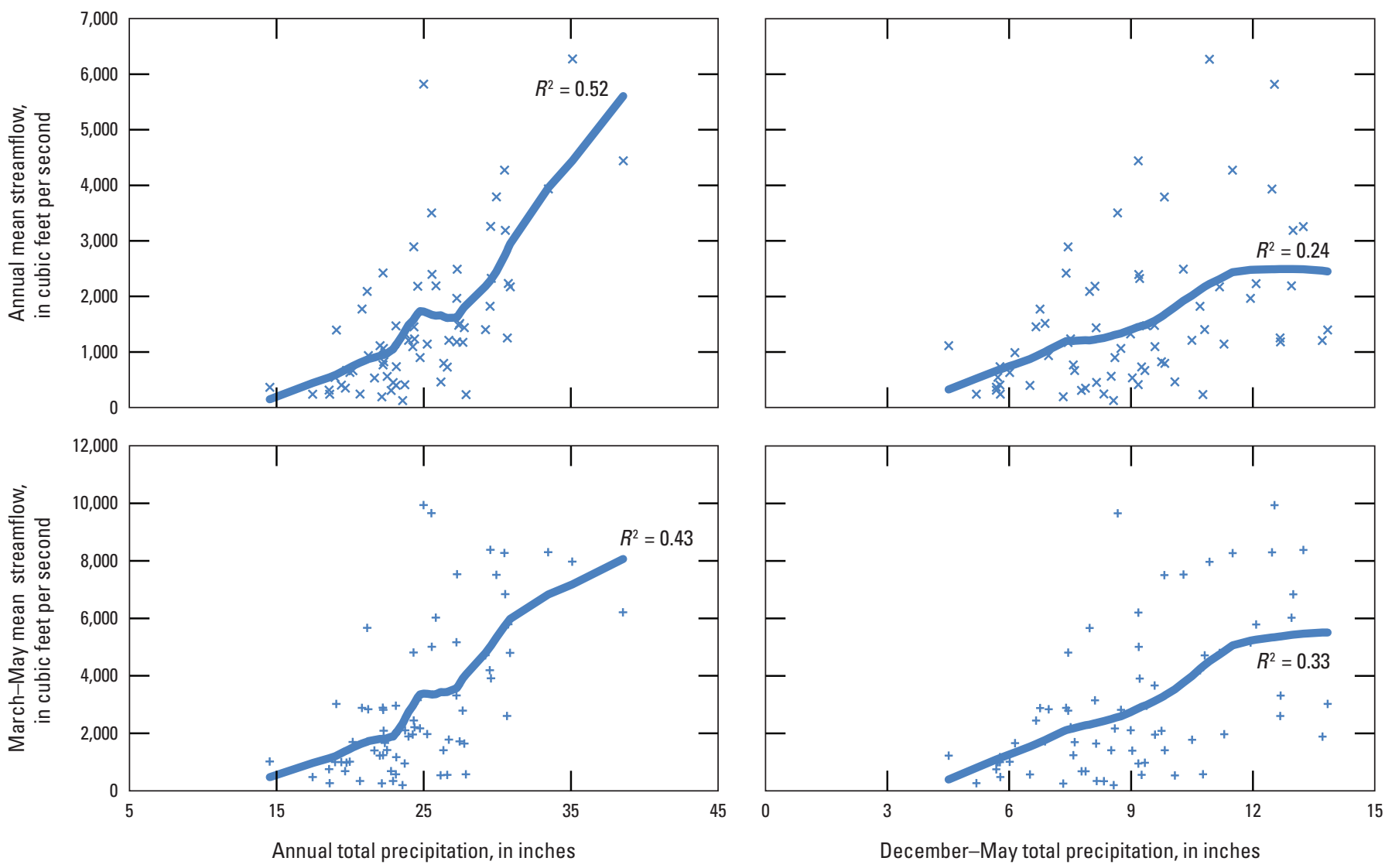

EXPLANATION

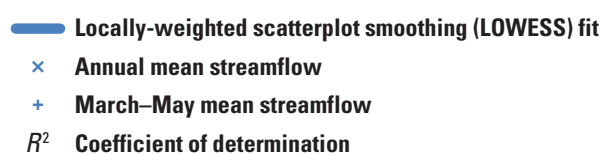

Figure 10. Relation between mean streamflow and total precipitation for annual and seasonal periods at selected streamgages, water years 1945-2013. A, Whetstone River near Big Stone City, South Dakota (streamgage 05291000). B, James River near Scotland, South Dakota (streamgage 06478500). C, Big Sioux River at Akron, lowa (streamgage 06485500)._Continued 
Table 5. Coefficients of determination $\left(R^{2}\right)$ for locally-weighted scatterplot smoothing models using precipitation as an explanatory variable for streamflow statistics within the same water year for water years 1945-2013.

[A water year (WY) is the 12-month period, October 1 through September 30, and is designated by the calendar year in which it ends. Mean $R^{2}$ values greater than 0.3 are shown in bold font. S. Dak., South Dakota; NA, not applicable]

\begin{tabular}{|c|c|c|c|c|c|}
\hline \multirow[b]{2}{*}{ Station name or statistic } & \multirow{2}{*}{$\begin{array}{c}\text { Streamgage } \\
\text { number }\end{array}$} & \multicolumn{4}{|c|}{ Streamflow statistic } \\
\hline & & $\begin{array}{c}\text { Annual } \\
\text { mean }\end{array}$ & $\begin{array}{l}\text { Annual 7-day } \\
\text { minimum }\end{array}$ & $\begin{array}{c}\text { March-May } \\
\text { mean }\end{array}$ & $\begin{array}{c}\text { March-May } \\
\text { minimum }\end{array}$ \\
\hline Whetstone River near Big Stone City, S. Dak. & 05291000 & 0.47 & 0.06 & 0.35 & 0.04 \\
\hline Elm River at Westport, S. Dak. & 06471500 & 0.25 & 0.09 & 0.15 & 0.29 \\
\hline Little Vermillion River near Salem, S. Dak. & 06478540 & 0.37 & $(1)$ & 0.21 & $\left({ }^{1}\right)$ \\
\hline West Fork Vermillion River near Parker, S. Dak. & 06478690 & 0.69 & 0.13 & 0.39 & 0.29 \\
\hline Big Sioux River near Watertown, S. Dak. & 06479438 & 0.37 & 0.11 & 0.34 & 0.09 \\
\hline Big Sioux River near Dell Rapids, S. Dak. & 06481000 & 0.37 & 0.07 & 0.26 & 0.05 \\
\hline \multicolumn{6}{|c|}{ March-May precipitation } \\
\hline Whetstone River near Big Stone City, S. Dak. & 05291000 & 0.15 & 0.04 & 0.11 & 0.15 \\
\hline Elm River at Westport, S. Dak. & 06471500 & 0.01 & 0.07 & 0.01 & 0.09 \\
\hline Firesteel Creek near Mount Vernon, S. Dak. & 06477500 & 0.30 & 0.05 & 0.40 & 0.07 \\
\hline James River near Scotland, S. Dak. & 06478500 & 0.11 & 0.07 & 0.11 & 0.01 \\
\hline Little Vermillion River near Salem, S. Dak. & 06478540 & 0.12 & $\left({ }^{1}\right)$ & 0.20 & $\left({ }^{1}\right)$ \\
\hline West Fork Vermillion River near Parker, S. Dak. & 06478690 & 0.10 & 0.06 & 0.20 & 0.10 \\
\hline Big Sioux River near Watertown, S. Dak. & 06479438 & 0.12 & 0.11 & 0.13 & 0.06 \\
\hline Big Sioux River near Dell Rapids, S. Dak. & 06481000 & 0.08 & 0.03 & 0.10 & 0.05 \\
\hline Elm River at Westport, S. Dak. & 06471500 & 0.12 & 0.07 & 0.12 & 0.09 \\
\hline Firesteel Creek near Mount Vernon, S. Dak. & 06477500 & 0.41 & 0.04 & 0.49 & 0.16 \\
\hline James River near Scotland, S. Dak. & 06478500 & 0.22 & 0.08 & 0.19 & 0.02 \\
\hline Little Vermillion River near Salem, S. Dak. & 06478540 & 0.12 & $\left({ }^{1}\right)$ & 0.22 & $\left({ }^{1}\right)$ \\
\hline West Fork Vermillion River near Parker, S. Dak. & 06478690 & 0.17 & 0.05 & 0.30 & 0.06 \\
\hline Big Sioux River near Watertown, S. Dak. & 06479438 & 0.34 & 0.07 & 0.33 & 0.11 \\
\hline Big Sioux River near Dell Rapids, S. Dak. & 06481000 & 0.21 & 0.08 & 0.25 & 0.08 \\
\hline Skunk Creek at Sioux Falls, S. Dak. & 06481500 & 0.25 & 0.06 & 0.33 & 0.08 \\
\hline Big Sioux River at Akron, Iowa & 06485500 & 0.24 & 0.06 & 0.33 & 0.05 \\
\hline Mean $R^{2}$ & NA & 0.24 & 0.06 & 0.29 & 0.08 \\
\hline
\end{tabular}

${ }^{1}$ The 7-day minimum value equals zero during at least 25 percent of water years in streamflow record, and therefore, was excluded from trend testing. 
Table 6. Statistics for precipitation-removed streamflow trends, water years 1945-2013 and 1980-2013.

[A water year (WY) is the 12-month period, October 1 through September 30, and is designated by the calendar year in which it ends. Shading denotes presence of a significant upward trend ( $p$-value less than 0.10). Sen slope is in units of cubic foot per second per year. S. Dak., South Dakota]

\begin{tabular}{|c|c|c|c|c|c|c|}
\hline \multirow{2}{*}{ Station name } & \multirow{2}{*}{$\begin{array}{c}\text { Streamgage } \\
\text { number }\end{array}$} & \multirow{2}{*}{ Statistic } & \multicolumn{2}{|c|}{ Annual mean streamflow ${ }^{1}$} & \multicolumn{2}{|c|}{$\begin{array}{c}\text { March-May } \\
\text { mean streamflow }\end{array}$} \\
\hline & & & $\begin{array}{c}\text { WYs } \\
1945-2013\end{array}$ & $\begin{array}{c}\text { WYs } \\
\text { 1980-2013 }\end{array}$ & $\begin{array}{c}\text { WYs } \\
1945-2013\end{array}$ & $\begin{array}{c}\text { WYs } \\
1980-2013\end{array}$ \\
\hline \multirow[t]{2}{*}{ Whetstone River near Big Stone City, S. Dak. } & 05291000 & $p$-value & 0.057 & 0.131 & 0.110 & 0.260 \\
\hline & & Sen slope & 0.499 & 1.32 & 0.899 & 2.30 \\
\hline \multirow[t]{2}{*}{ Elm River at Westport, S. Dak. } & 06471500 & $p$-value & 0.820 & 0.192 & 0.697 & 0.534 \\
\hline & & Sen slope & 0.059 & 0.944 & 0.349 & 1.64 \\
\hline \multirow[t]{2}{*}{ Firesteel Creek near Mount Vernon, S. Dak. } & 06477500 & $p$-value & 0.705 & 0.929 & 0.339 & 0.260 \\
\hline & & Sen slope & 0.065 & 0.036 & -0.493 & -1.65 \\
\hline \multirow[t]{2}{*}{ James River near Scotland, S. Dak. } & 06478500 & $p$-value & 0.160 & 0.058 & 0.622 & 0.313 \\
\hline & & Sen slope & 4.98 & 25.8 & 3.78 & 31.9 \\
\hline \multirow[t]{2}{*}{ Little Vermillion River near Salem, S. Dak. } & 06478540 & $p$-value & $\left({ }^{3}\right)$ & 0.955 & $\left({ }^{3}\right)$ & 0.736 \\
\hline & & Sen slope & $\left({ }^{3}\right)$ & -0.005 & $\left({ }^{3}\right)$ & -0.116 \\
\hline \multirow[t]{2}{*}{ West Fork Vermillion near Parker, S. Dak. } & 06478690 & $p$-value & $\left({ }^{3}\right)$ & 0.286 & $\left({ }^{3}\right)$ & 0.906 \\
\hline & & Sen slope & $\left({ }^{3}\right)$ & 0.678 & $\left({ }^{3}\right)$ & -0.137 \\
\hline \multirow[t]{2}{*}{ Big Sioux River near Watertown, S. Dak. } & 06479438 & $p$-value & $\left({ }^{3}\right)$ & 0.374 & $\left({ }^{3}\right)$ & 0.343 \\
\hline & & Sen slope & $\left({ }^{3}\right)$ & 0.278 & $\left({ }^{3}\right)$ & 0.946 \\
\hline \multirow[t]{2}{*}{ Big Sioux River near Dell Rapids, S. Dak. } & 06481000 & $p$-value & 0.014 & 0.722 & 0.117 & 0.767 \\
\hline & & Sen slope & 3.61 & 1.42 & 7.18 & 6.10 \\
\hline \multirow[t]{2}{*}{ Skunk Creek at Sioux Falls, S. Dak. } & 06481500 & $p$-value & 0.007 & 0.615 & 0.018 & 0.615 \\
\hline & & Sen slope & 1.30 & 0.809 & 3.07 & 3.37 \\
\hline \multirow[t]{2}{*}{ Big Sioux River at Akron, Iowa } & 06485500 & $p$-value & 0.001 & 0.790 & 0.085 & 0.790 \\
\hline & & Sen slope & 13.6 & 4.94 & 18.2 & 8.72 \\
\hline
\end{tabular}

${ }^{1}$ Annual total precipitation was used as a predictor of annual mean streamflow, by water year.

${ }^{2}$ March-May total precipitation was used as a predictor of March-May mean streamflow.

${ }^{3}$ Statistics not included for the period WYs 1945-2013 because of short streamflow record length (beginning after WY 1960; table 1). 

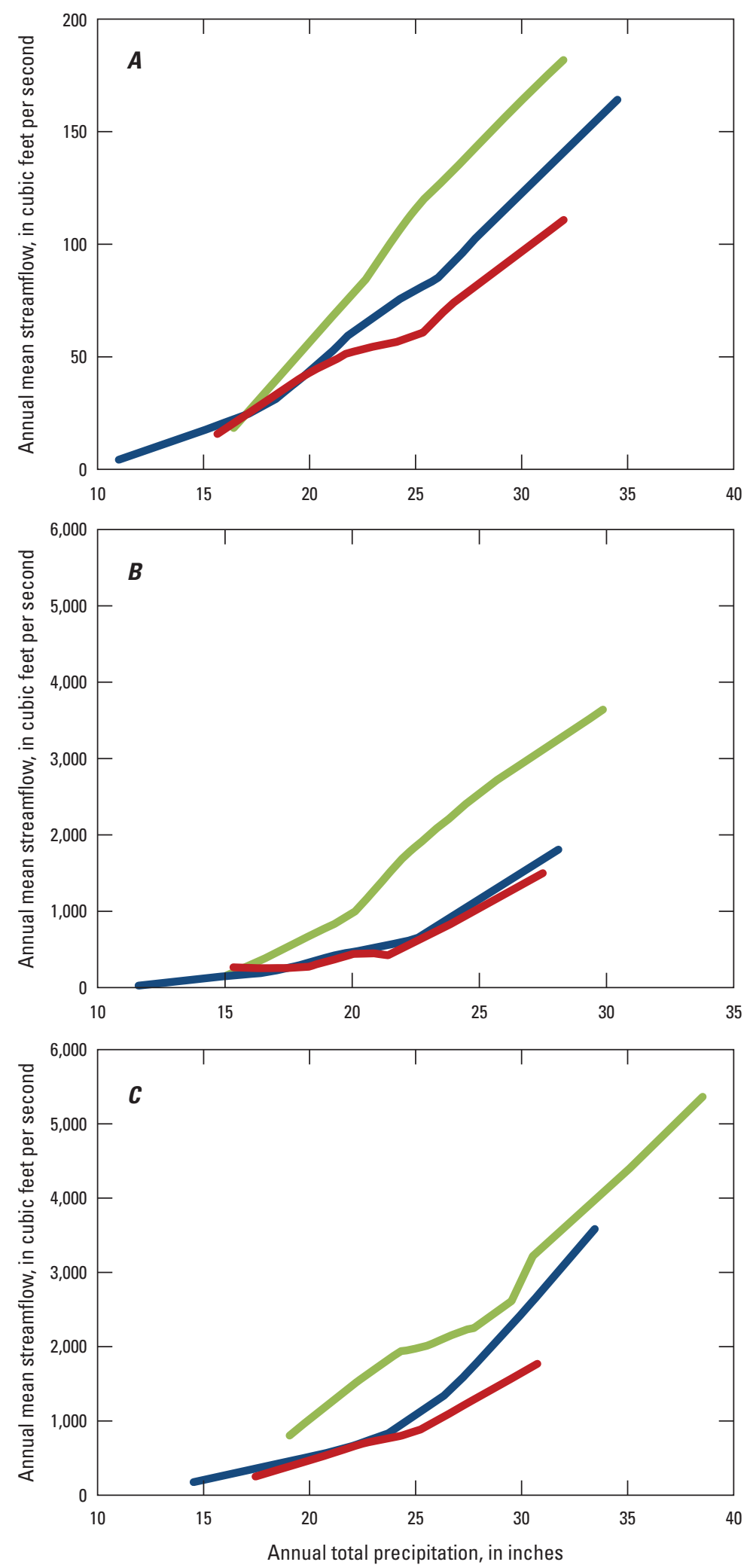

\section{EXPLANATION}

Locally-weighted scatterplot smoothing model for water years:

-1991-2013

1968-1990

$\longrightarrow$ 1945-1967
Figure 11. Precipitation-streamflow statistical models (locally-weighed scatterplot smoothing) for three periods. $A$, Whetstone River near Big Stone City, South Dakota (streamgage 05291000). B, James River near Scotland, South Dakota (streamgage 06478500). $C$, Big Sioux River at Akron, lowa (streamgage 06485500). 

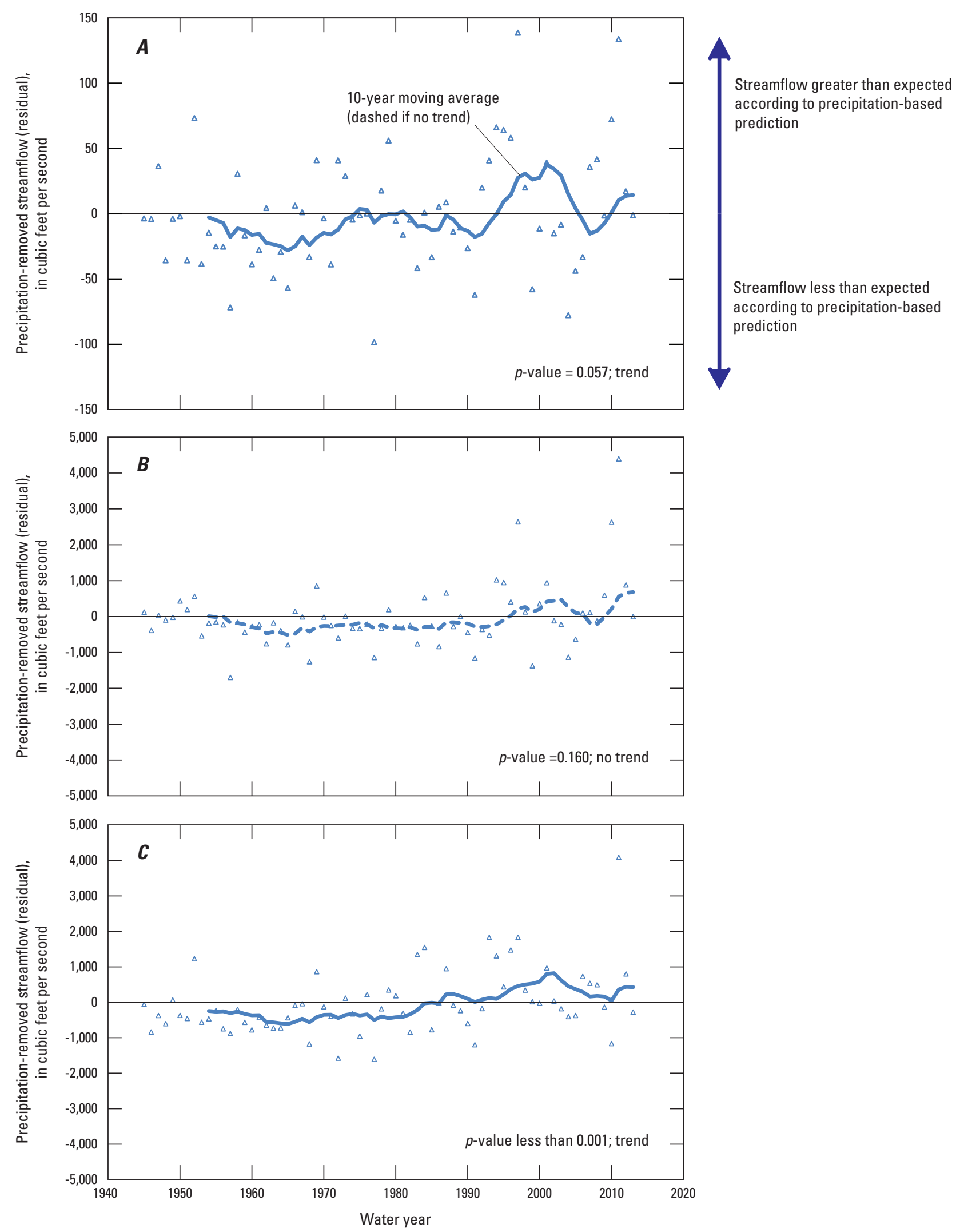

Figure 12. Time-series plots of annual precipitation-removed streamflow, water years 1945-2013. A, Whetstone River near Big Stone City, South Dakota (streamgage 05291000). B, James River near Scotland, South Dakota (streamgage 06478500). C, Big Sioux River at Akron, lowa (streamgage 06485500). The 10-year moving average (decadal mean) is dashed when the trend is not significant according to the Kendall tau test at the 0.1 significance level. 
For all watersheds, annual total precipitation as a predictor of annual mean streamflow (columns 4-5 in table 6) had a mean $R^{2}$ of 0.47 (table 5). Precipitation-removed streamflow (residuals about the LOWESS models) had significant trends (table 6) for WYs 1945-2013 in one-half of the streamgages included in the analyses, indicating that factors other than precipitation caused the upward trend identified at these streamgages. Trends in precipitation-removed streamflow were indicated for the Whetstone River near Big Stone City and the lower part of the Big Sioux River Basin-Big Sioux River near Dell Rapids, S. Dak. (streamgage 06481000), Skunk Creek at Sioux Falls, and Big Sioux River at Akron. The James River near Scotland had a significant upward trend in residuals for WYs 1980-2013, indicating that factors other than precipitation are important in explaining streamflow variation at this streamgage. The magnitude of these trends in precipitation-removed streamflow ranges from about $0.50\left(\mathrm{ft}^{3} / \mathrm{s}\right) / \mathrm{yr}$ for the Whetstone River at Big Stone City to $25.8\left(\mathrm{ft}^{3} / \mathrm{s}\right) / \mathrm{yr}$ for the James River at Scotland. These magnitudes are similar to the trends noted in the trend tests for annual mean streamflow, representing an increase of 0.70 to 3.0 percent of the long-term mean annual streamflow each year.

When the March-May mean streamflow is used as the streamflow statistic (columns 6-7 in table 6), annual precipitation explains the streamflow variability in all but two streamagages included in the analyses (Skunk Creek at Sioux Falls and Big Sioux River at Akron, each in the WY 1945-2013 period); these two streamgages have significant upward trends. The magnitudes of these trends are 3.07 and $18.2\left(\mathrm{ft}^{3} / \mathrm{s}\right) / \mathrm{yr}$ for Skunk Creek at Sioux Falls and Big Sioux River at Akron, respectively. Based on these results, the streamgages on the Whetstone and Big Sioux Rivers are characterized differently than those on the James and Vermillion Rivers (located to the west of the Whetstone and Big Sioux Rivers, fig. 1). Most streamgages in the Whetstone River and Big Sioux River Basins have streamflow trends that are not completely explained by precipitation during WYs 1945-2013 (table 6). In contrast, most streamgages in the James and Vermillion River Basins had no trends in residual annual mean streamflow, indicating streamflow trends can be explained primarily by precipitation. This conclusion generally is supported by the trends in precipitation (table 3 ), because there is more evidence of increasing precipitation in the James and Vermillion River Basins than in the Whetstone and Big Sioux River Basins during WYs 1945-2013. The March-May season of the more recent WY 1980-2013 period shows that precipitation-removed streamflow has no trends for all of the selected streamgages in eastern South Dakota.

Factors other than precipitation that affect streamflow can include anthropogenic changes in the watersheds (land use) as well as natural climatic changes that affect hydrology. No attempt was made to quantify the statistical significance of these individual causal factors on streamflow trends presented in this report. In eastern South Dakota, agriculture was the predominant land use during WYs 1945-2013, and developed or urban areas account for only 6 percent of the area (Homer and others, 2015; fig. 2). Changes to agricultural lands may include grassland conversion, drainage improvements (ditching), or subsurface tile drainage. Although the basin-scale effects of these practices may be difficult to discern, they are likely to affect local-scale (field level) hydrology. Changes in precipitation-removed streamflow during WYs 1945-2013 are more likely attributed to a shift in climatological patterns. For example, changes in timing or intensity of precipitation within a season or changes in precipitation type (rain or snow) may not be reflected in the total precipitation records (Ryberg and others, 2014). Mallakpour and Villarini (2015) identified sparse evidence for changes in the magnitude of heavy rainfall but determined a stronger tendency towards increases in the frequency of heavy rainfall days in the north-central United States. Thus, for the streamgages with significant trends in precipitation-removed streamflow (such as those in the Whetstone and Big Sioux River Basins), and where precipitation totals are relatively constant, a major causal factor for the streamflow increases probably is the timing and frequency of large precipitation events.

Another hydrological factor affecting streamflow is the antecedent hydrologic condition of the watershed. Regression analyses indicate that precipitation from the two previous water years is an important factor affecting annual mean streamflow and the 7-day minimum streamflow (table 7). For each streamgage, total precipitation from the current WY, previous water year (WY-1), and water year from 2 years previous (WY-2) were included as explanatory variables in a multiple linear regression analysis using annual mean streamflow and 7-day minimum streamflow as the dependent variables. Base flow is affected more by precipitation from preceding water years (WY-1 and WY-2) than from the current WY, based on the non-significant relations ( $p$-values greater than or equal to 0.10) for the 7-day minimum streamflow regression analyses for the current WY (table 7). Annual mean streamflows are affected by not only the current WY precipitation but also by the precipitation from the 2 preceding years (table 7).

Including precipitation totals from the previous 2 water years generally improves the precipitation-streamflow LOWESS models (fig. 11, table 8). For the LOWESS models considered in figure 11 and table 5, only the precipitation total from the current WY was used as the explanatory variable. When the sum of precipitation from the current WY and WY-1 was considered, mean $R^{2}$ values increased from 0.47 to 0.56 for annual mean streamflow statistic and increased from 0.11 to 0.34 for the 7-day minimum streamflow statistic (table 8). Including the WY-2 precipitation total in the LOWESS model generally yielded mean $R^{2}$ values that were similar to those for the current WY and WY-1 precipitation. Note the explanatory precipitation variables in table 8 (LOWESS analyses) are slightly different than those in table 7 (multiple linear regression analyses). The precipitation from previous years in table 8 is a cumulative amount (sum of current WY and $\mathrm{WY}-1$, and sum of current WY, WY-1, and WY-2) and those in table 7 are from a single water year. 
Table 7. Statistics for precipitation from current and preceding water years used as explanatory variables in multiple linear regression analyses for annual mean and 7-day minimum streamflow, water years 1945-2013.

[A water year (WY) is the 12-month period, October 1 through September 30, and is designated by the calendar year in which it ends. Shading denotes significant variable. S. Dak., South Dakota; WY-1, previous water year; WY-2, water year 2 years previous; <, less than; --, not available]

\begin{tabular}{|c|c|c|c|c|}
\hline \multirow[b]{2}{*}{ Station name } & \multirow{2}{*}{$\begin{array}{c}\text { Streamgage } \\
\text { number }\end{array}$} & \multirow{2}{*}{$\begin{array}{l}\text { Precipitation } \\
\text { variable }\end{array}$} & \multicolumn{2}{|c|}{$p$-value } \\
\hline & & & $\begin{array}{l}\text { Annual mean } \\
\text { streamflow }\end{array}$ & $\begin{array}{c}\text { Annual 7-day } \\
\text { minimum }\end{array}$ \\
\hline \multirow[t]{3}{*}{ Whetstone River near Big Stone City, S. Dak. } & 05291000 & Current WY & $<0.001$ & 0.245 \\
\hline & & WY-1 & $<0.001$ & $<0.001$ \\
\hline & & WY -2 & 0.028 & 0.006 \\
\hline \multirow[t]{3}{*}{ Elm River at Westport, S. Dak. } & 06471500 & Current WY & $<0.001$ & 0.572 \\
\hline & & WY -1 & 0.001 & $<0.001$ \\
\hline & & WY-2 & 0.104 & 0.003 \\
\hline \multirow[t]{3}{*}{ Firesteel Creek near Mount Vernon, S. Dak. } & 06477500 & Current WY & $<0.001$ & 0.911 \\
\hline & & WY-1 & 0.140 & $<0.001$ \\
\hline & & WY -2 & 0.035 & 0.248 \\
\hline \multirow[t]{3}{*}{ James River near Scotland, S. Dak. } & 06478500 & Current WY & $<0.001$ & 0.080 \\
\hline & & WY-1 & $<0.001$ & $<0.001$ \\
\hline & & WY-2 & 0.001 & $<0.001$ \\
\hline \multirow[t]{3}{*}{ Little Vermillion River near Salem, S. Dak. } & 06478540 & Current WY & $<0.001$ & -- \\
\hline & & WY-1 & 0.220 & -- \\
\hline & & WY -2 & 0.394 & -- \\
\hline \multirow[t]{3}{*}{ West Fork Vermillion near Parker, S. Dak. } & 06478690 & Current WY & $<0.001$ & 0.619 \\
\hline & & WY-1 & 0.006 & $<0.001$ \\
\hline & & WY -2 & 0.226 & 0.067 \\
\hline \multirow[t]{3}{*}{ Big Sioux River near Watertown, S. Dak. } & 06479438 & Current WY & $<0.001$ & 0.120 \\
\hline & & WY -1 & 0.003 & $<0.001$ \\
\hline & & WY-2 & 0.040 & 0.411 \\
\hline \multirow[t]{3}{*}{ Big Sioux River near Dell Rapids, S. Dak. } & 06481000 & Current WY & $<0.001$ & 0.126 \\
\hline & & WY-1 & $<0.001$ & $<0.001$ \\
\hline & & WY-2 & 0.004 & 0.002 \\
\hline \multirow[t]{3}{*}{ Skunk Creek at Sioux Falls, S. Dak. } & 06481500 & Current WY & $<0.001$ & 0.846 \\
\hline & & WY-1 & $<0.001$ & $<0.001$ \\
\hline & & WY -2 & 0.034 & 0.017 \\
\hline \multirow[t]{3}{*}{ Big Sioux River at Akron, Iowa } & 06485500 & Current WY & $<0.001$ & 0.124 \\
\hline & & WY-1 & $<0.001$ & $<0.001$ \\
\hline & & WY-2 & 0.023 & 0.004 \\
\hline
\end{tabular}




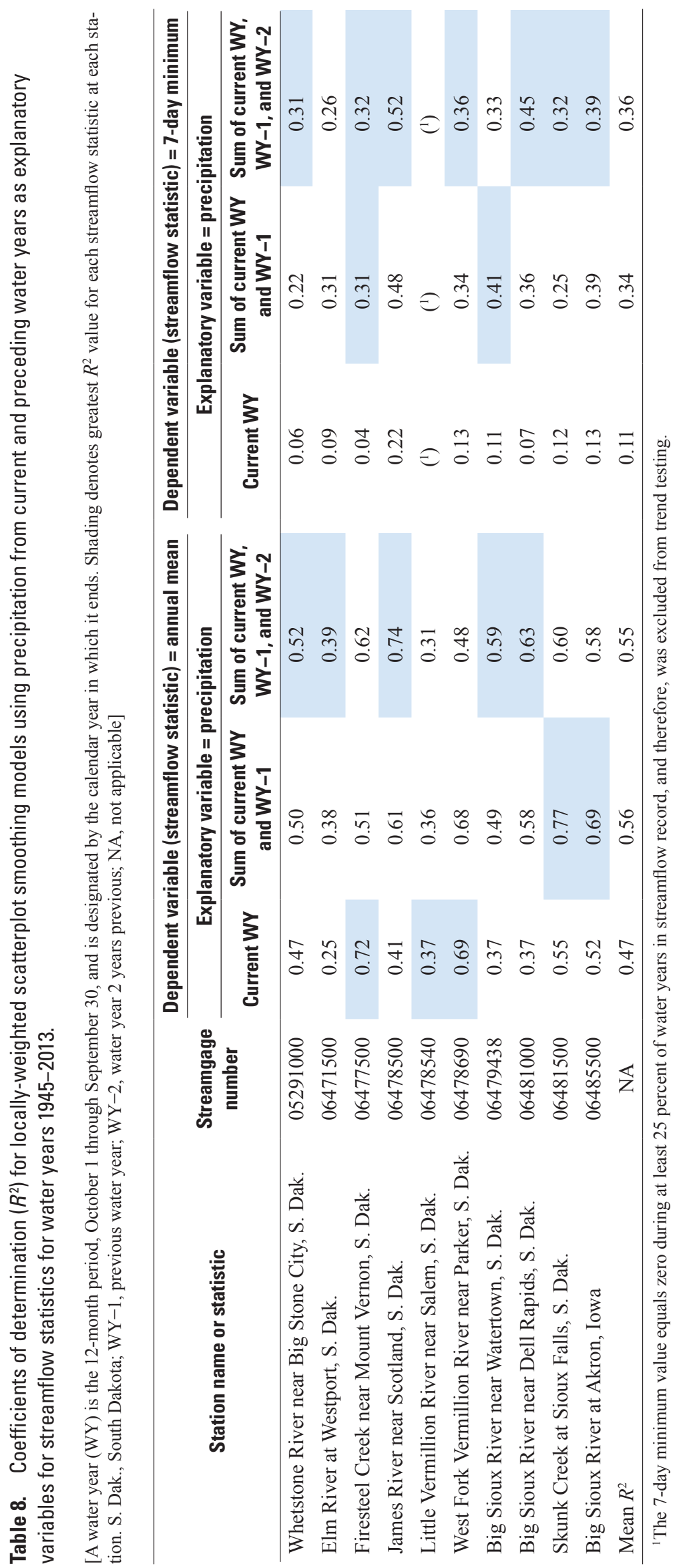


Climate and Streamflow Characteristics for Selected Streamgages in Eastern South Dakota, Water Years 1945-2013

The information presented in tables 7 and 8 allow for a characterization of which sites are more buffered from variability during wet and dry climatic cycles. Streamflow in the James River near Scotland is explained best using the combined precipitation total from the current and previous 2 water years, as indicated by much greater $R^{2}$ values in the LOWESS models for both mean and 7-day minimum streamflows (table 8 ) and very low $p$-values associated with the precipitation variables $\mathrm{WY}-1$ and $\mathrm{WY}-2$ in a multiple linear regression analyses (table 7). Conversely, the best LOWESS models (as indicated by the greatest $R^{2}$ values) for annual mean streamflow for three streamgages (Firesteel Creek near Mount Vernon, Little Vermillion River near Salem, and West Fork Vermillion River near Parker) use only the current WY precipitation total (table 8). In examining the multiple linear regression models for these three streamgages, at least one precipitation variable for previous water years (WY-1 or WY-2) was not significant in explaining annual mean streamflow (table 7). Streamflow at these three streamgages might be more susceptible to large swings in streamflow in any given year and more responsive to the precipitation that occurs in the current year. Larger rivers in eastern South Dakota (such as the James River near Scotland or Big Sioux River at Akron) probably are more buffered because excess precipitation is stored in groundwater or soil moisture reservoirs and released on a multi-annual time scale. These analyses indicate that groundwater may play an important role in annual mean and 7-day minimum streamflow in these watersheds.

Although trend test results for precipitation-removed streamflow indicate that increased streamflow in several eastern South Dakota watersheds can be explained primarily through a change in annual precipitation, other explanations are needed to describe the increased runoff efficiency (fig. 11). The main-stem rivers (Big Sioux, James, and Vermillion Rivers) are underlain by shallow alluvial aquifers where the groundwater is hydraulically connected to the surface water. Channel slope in these basins is anomalously gentle (Moody and others, 1986), and therefore watersheds are slow to drain runoff from precipitation events, with greater potential for runoff to recharge the groundwater systems in these watersheds. In addition, surface-water drainage is slowed by the extensive depression storage available in the Prairie Pothole Region. In tributaries of the main-stem rivers, groundwater commonly persists in the sand, gravel, and till deposits at depths less than $20 \mathrm{ft}$ (Lawrence and Sando, 1991). Groundwater-level records for three monitoring wells in the central James River
Table 9. Information for three monitoring wells in the James River Basin (from South Dakota Department of Environment and Natural Resources, 2015).

\begin{tabular}{ccc}
\hline $\begin{array}{c}\text { Well identifier } \\
\text { (fig. 1) }\end{array}$ & $\begin{array}{c}\text { Depth } \\
\text { (feet) }\end{array}$ & $\begin{array}{c}\text { Distance from } \\
\text { James River }\end{array}$ \\
\hline SP-53A & 41.4 & 5 miles west \\
SP-53B & 49.5 & 11 miles west \\
SP-60B & 35.0 & 23 miles east \\
\hline
\end{tabular}

Basin (fig. 1, table 9; South Dakota Department of Environmental and Natural Resources, 2015) show decadal mean groundwater-level increases of approximately $5-10 \mathrm{ft}$ between the 1970s and 2010s (fig. 13). Increasingly high groundwater levels after 1980 coincide with increases noted in streamflow during the same period (fig. 6). Although these three wells are located in the central part the James River Basin, the general temporal patterns in groundwater levels of the wells are considered reasonably representative of groundwater conditions in much of eastern South Dakota for this report. The bedrock underlying the glacial deposits in the vicinity of the monitoring wells consists of Cretaceous-age shales. Small parts of the James River Basin to the south of the monitoring wells have bedrock consisting of Cretaceous-age sandstones and Precambrian-age rocks. In general, the James River Basin and other basins in eastern South Dakota have a geologic setting where loss of groundwater to underlying bedrock would be small. The high groundwater levels are hypothesized to contribute to increased surface runoff caused by greater potential for saturated conditions or reduced infiltration capacity near the land surface particularly during precipitation events. Upward trends in precipitation (fig. 8), gentle slope of main-stem stream channels, extensive shallow glacial aquifers, and underlying bedrock that inhibits or prevents loss of groundwater to deeper geologic units all combine to create a setting where groundwater plays a large role in the characteristics of streamflow in eastern South Dakota. The role of groundwater in the streamflow characteristics of eastern South Dakota is supported by the significance of antecedent conditions (table 7) and the recent increases in the runoff efficiency of watersheds (fig. 11) that are associated with upward trends in groundwater levels (fig. 13) to within 5 to $10 \mathrm{ft}$ below land surface. 


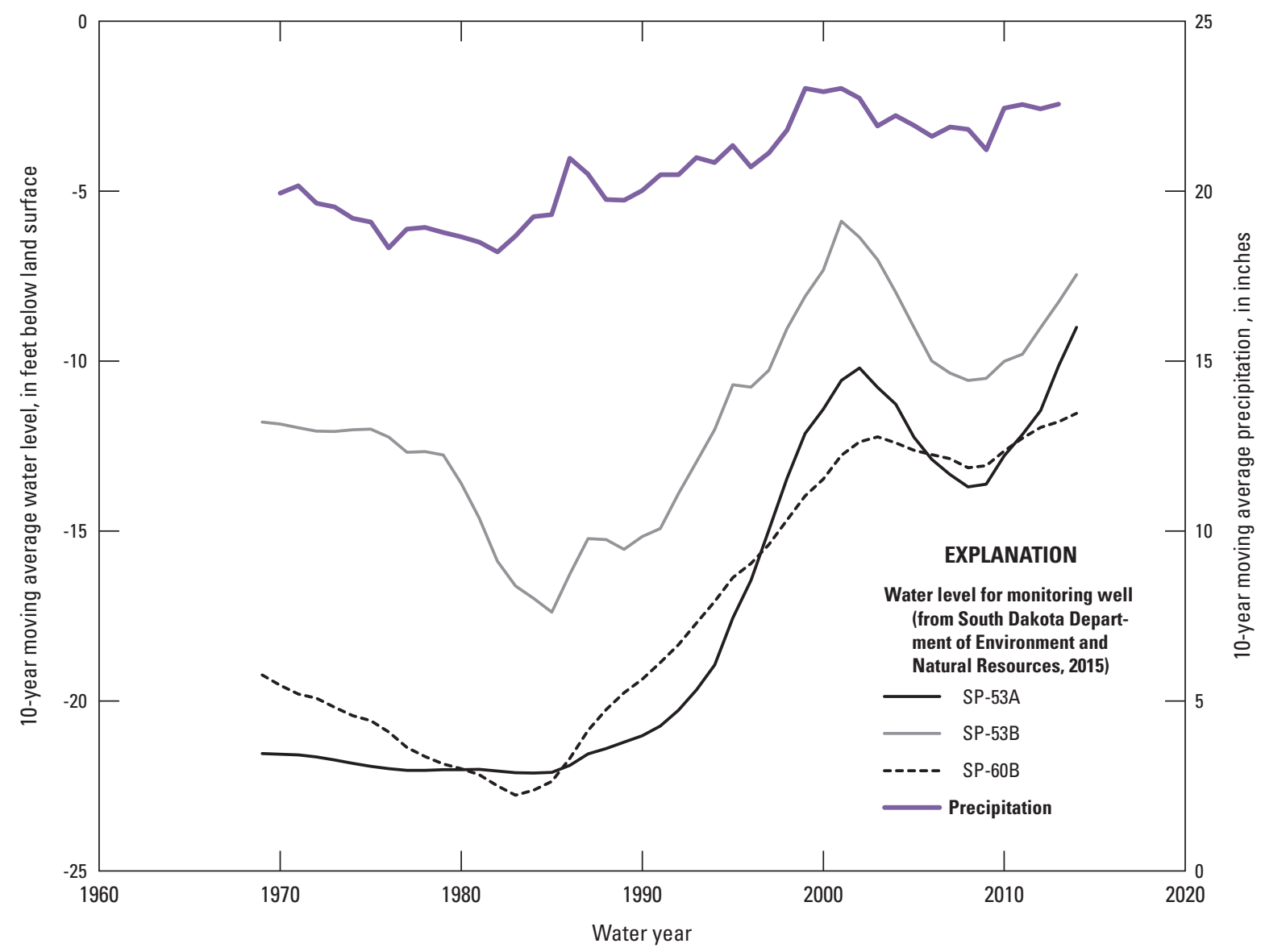

Figure 13. Groundwater levels for three monitoring wells and precipitation totals in the James River Basin, water years 19532013.

\section{Summary}

Upward trends in precipitation and streamflow have been observed in the northeastern Missouri River Basin during the past century, including the area of eastern South Dakota. Some of the identified upward trends were anomalously large relative to surrounding parts of the northern Great Plains. Forcing factors for streamflow trends in eastern South Dakota are not well understood, and it is not known whether streamflow trends are driven primarily by climatic changes or various land-use changes. Understanding the effects that climate (specifically precipitation and temperature) has on streamflow characteristics within a region will help to better understand additional factors such as land-use alterations that may affect the hydrology of the region. To aid in this understanding, a study was completed by the U.S. Geological Survey, in cooperation with the East Dakota Water Development District and James River Water Development District, to assess trends in climate and streamflow characteristics at 10 selected streamgages in eastern South Dakota for water years (WYs) 1945-2013 (69 years) and WYs 1980-2013 (34 years). A WY is the 12-month period, October 1 through September 30 , and is designated by the calendar year in which it ends.
One streamgage is on the Whetstone River, a tributary to the Minnesota River, and the other streamgages are in the James, Big Sioux, and Vermillion River Basins. The watersheds for two of the James River streamgages extend into North Dakota, and parts of the watersheds for two of the Big Sioux River streamgages extend into Minnesota and Iowa. The objectives of this study were to document trends in streamflow and precipitation in these watersheds, and characterize the residual streamflow variability that might be attributed to factors other than precipitation. Residuals were computed as the departure from a locally-weighted scatterplot smoothing (LOWESS) model. Significance of trends was based on the Mann-Kendall nonparametric test at a 0.10 significance level.

Statistical analyses provide a representative overview and interpretation of the streamflow and precipitation datasets. Streamflow values were summarized into four statistical groups for analyses by WY: (1) annual mean streamflow, (2) annual 7-day minimum streamflow, (3) mean daily streamflow for the March-May period; and (4) 7-day minimum streamflow for the March-May period. Precipitation and air temperature for the watershed areas of the 10 streamgages were analyzed for trends and described in their relation to streamflow using several seasonal periods in addition to the 
annual (by WY) period. In other analyses, the variation in streamflow explained by precipitation was removed, which allowed focus on variables that affect streamflow but are not associated with precipitation.

Of the 10 streamgages selected, only the Elm River at Westport (which is affected by reservoir regulation) did not have a significant upward trend in annual mean streamflow for WYs 1945-2013. The magnitude of trends in annual mean streamflow (characterized by Sen slopes) ranged from 0.269 cubic feet per second per year $\left(\left[\mathrm{ft}^{3} / \mathrm{s}\right] / \mathrm{yr}\right)$ at Firesteel Creek near Mount Vernon to $10.5\left(\mathrm{ft}^{3} / \mathrm{s}\right) / \mathrm{yr}$ at the James River near Scotland. All streamgages had upward trends in annual 7-day minimum streamflow during WYs 1945-2013. One-half of the streamgages had significant upward trends in annual mean streamflow for WYs 1980-2013. Annual mean streamflow and 7-day minimum streamflows also had an upward trend for the spring runoff period (March-May) at most streamgages during WYs 1945-2013. Significant precipitation trends for WYs 1945-2013 are less prevalent than streamflow trends in eastern South Dakota. Total annual precipitation had a significant upward trend for watersheds of 4 of the 10 streamgages during WYs 1945-2013, but no trends were significant for WYs 1980-2013. The most widespread seasonal precipitation increase was indicated for the months of September-November, with significant trends indicated for 8 of 10 streamgages for WYs 1945-2013. The greatest magnitude of increase in precipitation was for the December-May season during WYs 1980-2013, which had Sen slopes averaging 0.106 inch per year (in/yr) for the six watersheds with significant trends. Sen slopes for annual and March-May total precipitation were less than $0.075 \mathrm{in} / \mathrm{yr}$ for the watersheds of streamgages with significant trends. Trend magnitudes for the SeptemberNovember season were low, averaging only $0.028 \mathrm{in} / \mathrm{yr}$. No trends in maximum air temperatures were identified for WYs 1945-2013, with the exception of one downward trend in the July-September season for the Big Sioux River at Akron. Minimum air temperatures for all watersheds had upward trends in all seasons (except for October-December).

Locally-weighted scatterplot smoothing (LOWESS) models were used to describe the relation between precipitation and streamflow. The highest LOWESS correlation was between annual precipitation and annual mean streamflow (mean coefficient of determination of 0.47 ), whereas base flow as a function of precipitation (those involving 7-day minimum streamflows) had the poorest correlation (mean coefficient of determination less than 0.10). Changes in the relations between precipitation and streamflow in eastern South Dakota since 1945 are evident when considering the runoff efficiency (the amount of runoff that is generated for a given amount of precipitation) of the watershed. For an annual precipitation total of 25 inches, the expected streamflow of the James River near Scotland increased from about 1,000 cubic feet per second during WYs 1945-1990 to about 2,500 cubic feet per second during WYs 1991-2013.

A significant trend in the precipitation-removed streamflow (residuals of the LOWESS relations) indicates that factors other than precipitation affect streamflow, and conversely, non-significant trends indicate that precipitation explains most of the streamflow variability. Using annual precipitation as a predictor of annual mean streamflow, precipitation-removed streamflow had significant trends during WYs 1945-2013 for one-half of the streamgages included in the analyses. Trends in precipitation-removed streamflow were indicated for the Whetstone River near Big Stone City and the lower part of the Big Sioux River Basin, indicating that factors other than precipitation are major contributors to streamflow variability during the period. The James River near Scotland, S. Dak., had a trend in residuals during WYs 1980-2013. The magnitude of these trends in precipitation-removed streamflow ranges from about $0.50\left(\mathrm{ft}^{3} / \mathrm{s}\right) / \mathrm{yr}$ for the Whetstone River at Big Stone City, S. Dak., to $25.8\left(\mathrm{ft}^{3} / \mathrm{s}\right) / \mathrm{yr}$ for the James River at Scotland, S. Dak. Annual precipitation explains the March-May streamflow variability in all but two streamgages (Skunk Creek at Sioux Falls, S. Dak., and Big Sioux River at Akron, Iowa) for WYs 1945-2013. Most streamgages in the Whetstone River and Big Sioux River Basins have streamflow trends that are not completely explained by precipitation during WYs 1945-2013. In contrast, most streamgages in the James and Vermillion River Basins had no trends in residual annual mean streamflow, indicating streamflow trends can be explained primarily by precipitation. No trends in precipitation-removed streamflow were significant for the March-May season during WYs 1980-2013 for any of the selected streamgages in eastern South Dakota.

Factors other than precipitation that can affect streamflow include anthropogenic changes to the watersheds (land use) and natural climatic changes that affect hydrology. For example, changes in timing or intensity of precipitation with a season or changes in precipitation type (rain or snow) may not be reflected in the total precipitation records. Although some agricultural land in eastern South Dakota has experienced changing land management practices, the prevailing land use remained relatively constant during WYs 1945-2013. For the streamgages with significant trends in precipitation-removed streamflow (Whetstone River and those in the Big Sioux River Basin), and where precipitation totals are relatively constant, the main causal factor for the streamflow increases probably is the timing and frequency of large precipitation events. Another important factor contributing to the higher flows is the antecedent hydrologic conditions of the watersheds when entering the spring season. Base flow is affected more by precipitation from preceding water years than from the current water year, and annual mean streamflows are affected by not only the current water year precipitation but also by the precipitation from the 2 preceding water years. Water levels have increased in shallow groundwater wells approximately $5-10$ feet between the 1970s and 2010s. Although not specifically investigated in this study, high groundwater levels are hypothesized to contribute to increased surface runoff with greater potential for saturated conditions or reduced infiltration capacity near the land surface particularly during precipitation events. 


\section{References Cited}

Adler, Joseph, 2010, R in a nutshell: Sebastopol, California, O’Reilly Media, $611 \mathrm{p}$.

Anderson, M.T., and Woosley, L.H., Jr., 2005, Water availability in the western United States-Key scientific challenges: U.S. Geological Survey Circular 1261, 85 p. [Also available at http://pubs.usgs.gov/circ/2005/circ1261/.]

Baker, N.T., Stone, W.W., Frey, J.W., and Wilson, J.T., 2007, Water and agricultural-chemical transport in a Midwestern, tile-drained watershed-Implications for conservation practices: U.S. Geological Survey Fact Sheet 2007-3084, 6 p., accessed August 28, 2015, at http://pubs.usgs.gov/ fs $/ 2007 / 3084 /$.

Bredehoeft, J.D., Neuzil, C.E., and Milly, P.C.D., 1983, Regional flow in the Dakota aquifer-A study of the role of confining layers: U.S. Geological Survey Water-Supply Paper 2237, 45 p. [Also available at http://pubs.er.usgs.gov/ publication/wsp2237.]

Coopersmith, E.J., Minsker, B.S., and Sivapalan, M., 2014, Patterns of regional hydroclimatic shifts - An analysis of changing hydrologic regimes: Water Resources Research, v. 50, no. 3, p. 1960-1983. [Also available at http://dx.doi. org/10.1002/2012WR013320.]

Daly, C.D., Gibson, W.P., Taylor, G.H., Johnson, G.L., and Pasteris, P., 2002, A knowledge-based approach to the statistical mapping of climate: Climate Research, v. 22, p. 99-113. [Also available at http://dx.doi.org/10.3354/ cr022099.]

Daly, C.D., Halbleib, M., Smith, J.I., Gibson, W.P., Doggett, M.K., Taylor, G.H., Curtis, J., and Pasteris, P.P., 2008, Physiographically sensitive mapping of climatological temperature and precipitation across the conterminous United States: International Journal of Climatology, v. 28, no. 15, p. 2031-2064. [Also available at http://dx.doi.org/10.1002/ joc.1688.]

Daly, C.D., Neilson, R.P., and Phillips, D.L., 1994, A statistical-topographic model for mapping climatological precipitation over mountainous terrain: Journal of Applied Meteorology, v. 33, no. 2, p. 140-158. [Also available at http:// dx.doi.org/10.1175/1520-0450(1994)033<0140:ASTMFM> 2.0.CO;2.]

Dettinger, M.D., 2005, Changes in streamflow timing in the western United States in recent decades: U.S. Geological Survey Fact Sheet 2005-3018, 4 p., accessed August 21, 2015, at http://pubs.usgs.gov/fs/2005/3018/.
Dettinger, M.D., and Cayan, D.R., 1995, Large-scale atmospheric forcing of recent trends toward early snowmelt runoff in California: Journal of Climate, v. 8, p. 606-623. [Also available at http://dx.doi.org/10.1175/15200442(1995)008<0606:LSAFOR>2.0.CO;2.]

Fenneman, N.M., 1931, Physiography of the Western United States: New York, McGraw Hill, 534 p. plus map.

Flint, R.F., 1955, Pleistocene geology of eastern South Dakota: U.S. Geological Survey Professional Paper 262, 173 p. [Also available at http://pubs.er.usgs.gov/publication/ pp262.]

Gibson, W.P., Daly, C., Kittel, T., Nychka, D., Johns, C., Rosenbloom, N., McNab, A., and Taylor, G., 2002, Development of a 103-year high-resolution climate data set for the conterminous United States: Proceedings, 13th Conference on Applied Climatology, American Meteorological Society, Portland, Oreg., May 13-16, 2002, p. 181-183.

Hay, C., 2012, Crop water use estimates: South Dakota State University Extension, accessed October 8, 2015, at http:// igrow.org/agronomy/corn/crop-water-use-estimates/.

Helsel, D.R., and Hirsch, R.M., 2002, Statistical methods in water resources: U.S. Geological Survey Techniques of Water Resources Investigations, book 4, chap. A3, 522 p., accessed August 28, 2015, at http://pubs.usgs.gov/twri/ twri4a3/.

Hirsch, R.H., 2011, A perspective on nonstationarity and water management: Journal of the American Water Resources Association, v. 47, p. 436-446. [Also available at http:// dx.doi.org/10.1111/j.1752-1688.2011.00539.x.]

Hirsch, R.M., and De Cicco, L.A., 2014, EGRET_-Exploration and Graphics for RivEr Trends (EGRET): R package version 2.1.0, accessed August 20, 2015, at http://CRAN.Rproject.org/package=EGRET.

Hirsch, R.H., and Ryberg, K.R., 2011, Has the magnitude of flood across the USA changed with global $\mathrm{CO}_{2}$ levels?: Hydrological Science Journal, v. 57, no. 1, p. 1-9. [Also available at http://dx.doi.org/10.1080/02626667.2011.6218 95.]

Homer, C.G., Dewitz, J.A., Yang, L., Jin, S., Danielson, P., Xian, G., Coulston, J., Herold, N.D., Wickham, J.D., and Megown, K., 2015, Completion of the 2011 National Land Cover Database for the conterminous United StatesRepresenting a decade of land cover change information: Photogrammetric Engineering and Remote Sensing, v. 81, no. 5, p. 345-354. 
Karl, T.R., and Knight, R.W., 1998, Secular trends of precipitation amount, frequency, and intensity in the United States: Bulletin of the American Meteorological Society, v. 79, p. 231-241. [Also available at http://dx.doi.org/10.1175/15200477(1998)079<0231:STOPAF>2.0.CO;2.]

Karl, T.R., Melillo, J.M., and Peterson, T.C., 2009, Global climate change impacts in the United States: Cambridge, England, Cambridge University Press, 188 p.

Kendall, M.G., 1938, A new measure of rank correlation: Biometricka, v. 30, p. 81-93. [Also available at http://dx.doi. org/10.1093/biomet/30.1-2.81.]

Lawrence, S.J., and Sando, S.K., 1991, Quality of water from surficial-outwash aquifers in the Big Sioux River Basin, eastern South Dakota: U.S. Geological Survey WaterResources Investigations Report 89-4170, 81 p. [Also available at http://pubs.er.usgs.gov/publication/wri894170.]

Lins, H.F., 2005, Streamflow trends in the United States: U.S. Geological Survey Fact Sheet 2005-3017, 4 p., accessed August 21, 2015, at http://pubs.usgs.gov/fs/2005/3017/.

Lins, H.F., and Slack, J.R., 1999, Streamflow trends in the United States: Geophysical Research Letters, v. 26, no. 2, p. 227-230. [Also available at http://dx.doi. org/10.1029/1998GL900291.]

Lundstrom, S.C., Paces, J.B., Iles, D., and Cowman, T., 2009, Nature and timing of the latest Wisconsin advance of the James River lobe, South Dakota [abs]: Eos Transactions American Geophysical Union, v. 90, no. 52, Fall Meeting Supplement, Abstract PP21A-1332.

Mallakpour, Iman, and Villarini, Gabriele, 2015, The changing nature of flooding across the central United States: Nature Climate Change, v. 5, p. 250-254. [Also available at http:// dx.doi.org/10.1038/nclimate2516.]

Martin, J.E., Sawyer, J.F., Fahrenbach, M.D., Tomhave, D.W., and Schulz, L.D., 2004, Geologic map of South Dakota: South Dakota Department of Environment and Natural Resources, General Map 10, scale 1:500,000.

McCabe, G.J., and Wolock, D.M., 2002, A step increase in streamflow in the conterminous United States: Geophysical Research Letters, v. 29, no. 24, p. 2185. [Also available at http://dx.doi.org/10.1029/2002GL015999.]

McCabe, G.J., and Wolock, D.M., 2011, Independent effects of temperature and precipitation on modeled runoff in the conterminous United States: Water Resources Research, v. 47, 11 p. [Also available at http://dx.doi. org/10.1029/2011WR010630.]
Moody, D.W., Chase, E.B., and Aronson, D.A., 1986, National water summary 1985-Hydrologic events and surface-water resources: U.S. Geological Survey Water Supply Paper 2300, $506 \mathrm{p}$. [Also available at http://pubs.er.usgs.gov/publication/wsp2300.]

Morey, G.B., and Meints, J., 2000, Geologic map of Minnesota-Bedrock geology (3d ed.): Minnesota Geological Survey State Map Series S-20, scale 1:1,000,000, accessed September 16, 2015, at http:/www.mngeo.state.mn.us/ chouse/geology/statewide.html.

National Oceanic and Atmospheric Administration, 2015, The USHCN Version 2 serial monthly datasets: accessed August 10, 2015, at http://www.ncdc.noaa.gov/oa/climate/research/ ushen/.

Norton, P.A., Anderson, M.T., and Stamm, J.F., 2014, Trends in annual, seasonal, and monthly streamflow characteristics at 227 streamgages in the Missouri River watershed, water years 1960-2011: U.S. Geological Survey Scientific Investigations Report 2014-5053, 128 p., accessed August 28, 2015, at http://dx.doi.org/10.3133/sir20145053.

Ott, R.L., and Longnecker, M., 2001, An introduction to statistical methods and data analyses (5th ed.): Pacific Grove, Calif., Duxbury, 1152 p.

Pederson, G.T., Gray, S.T., Ault, T., Marsh, W., Fagre, D.B., Bunn, A.G., Woodhouse, C.A., and Graumlich, L.J., 2011, Climatic controls on the snowmelt hydrology of the Northern Rocky Mountains: Journal of Climate, v. 24, p. 1666-1687. [Also available at http://dx.doi. org/10.1175/2010JCLI3729.1.]

R Core Team, 2014, R-A language and environment for statistical computing: Vienna, Austria, R Foundation for Statistical Computing, accessed August 20, 2015, at http:// www.R-project.org.

Ryberg, K.R., Lin, W., and Vecchia, A.V., 2014, Impact of climate variability on runoff in the north-central United States: Journal of Hydrologic Engineering, v. 19, no. 1, p. 148-158. [Also available at http://dx.doi.org/10.1061/ (ASCE)HE.1943-5584.0000775.]

Sando, S.K., Driscoll, D.G., and Parrett, Charles, 2008, Peak-flow frequency estimates based on data through water year 2001 for selected streamflow-gaging stations in South Dakota: U.S. Geological Survey Scientific Investigations Report 2008-5104, 367 p., accessed August 24, 2015, at http://pubs.usgs.gov/sir/2008/5104/.

Sen, P.K., 1968, Estimates of regression coefficient based on Kendall's tau: Journal of the American Statistical Association, v. 63, p. 1379-1389. [Also available at http://dx.doi. org/10.2307/2285891.] 
Slack, J.R., and Landwehr, J.M., 1992, Hydro-Climatic Data Network (HCDN)_A U.S. Geological Survey streamflow data set for the United States for the study of climate variations, 1874-1988: U.S. Geological Survey Open-File Report 92-129, 193 p. [Also available at http://pubs.usgs. gov/of/1992/ofr92-129/.]

South Dakota Department of Environment and Natural Resources, 2015, Observation well measurements in South Dakota: accessed June 4, 2015, at http://denr.sd.gov/des/wr/ dbobsearch.aspx.

Theil, H., 1950, A rank-invariant method of linear and polynomial regression analysis, Parts 1, 2, and 3: Proceedings of the Royal Netherlands Academy of Sciences, v. 53, p. 386-392, 521-525, and 1397-1412.

Thomas, B.E., and Pool, D.R., 2006, Trends in streamflow of the San Pedro River, southeastern Arizona, and regional trends in precipitation and streamflow in southeastern Arizona and southwestern New Mexico: U.S. Geological Survey Professional Paper 1712, 79 p. [Also available at http://pubs.usgs.gov/pp/pp1712/.]

Tomhave, D.W., and Schulz, L.D., 2004, Bedrock geologic map showing configuration of the bedrock surface in South Dakota east of the Missouri River: South Dakota Department of Environment and Natural Resources, General Map 9, 1:500,000 scale, accessed August 24, 2015, at http:// www.sdgs.usd.edu/pubs/pdf/G-09.pdf.
U.S. Department of Agriculture, 2012, Farm Service Agency: accessed August 3, 2012, at http:/www.fsa.usda.gov/FSA/ webapp area $=$ home\&subject $=$ rsch $\&$ topic $=$ css.

U.S. Geological Survey, 2014, National Water Information System: accessed August 1, 2014, at http://waterdata.usgs. gov/sd/nwis/.

Walsh, J., Wuebbles, D., Hayhoe, K., Kossin, J., Kunkel, K., Stephens, G., Thorne, P., Vose, R., Wehner, M., Willis, J., Anderson, D., Doney, S., Feely, R., Hennon, P., Kharin, V., Knutson, T., Landerer, F., Lenton, T., Kennedy, J., and Somerville, R., 2014, Our changing climate, in Melillo, J.M., Richmond, T.C., and Yohe, G.W., eds., Climate change impacts in the United States - The third national climate assessment: U.S. Global Change Research Program, p. 19-67.

Whitehead, R.L., 1996,Groundwater atlas of the United States-Segment 8, Montana, North Dakota, South Dakota, Wyoming: U.S. Geological Survey Hydrologic Atlas 730-I, $24 \mathrm{p}$.

Witzke, B.J., Anderson, R.R., and Pope, J.P., 2010, Bedrock geologic map of Iowa: Iowa City, Iowa Geological and Water Survey, scale 1:500,000, accessed August 20, 2015, at http://s-iihr34.iihr.uiowa.edu/publications/uploads/M-22. pdf. 



\section{Appendix}

A complete listing of the streamflow and precipitation time-series data for the 10 streamgages investigated in this report are presented in the Microsoft ${ }^{\circledR}$ Excel file at http://dx.doi.

org/10.3133/sir20155146. The Microsoft ${ }^{\circledR}$ Excel file contains 11 worksheets: the first ("info") contains a general description of the worksheets and abbreviations, followed by a separate sheet for the streamflow and precipitation data for each streamgage (named by its U.S. Geological Survey streamgage number). 
Publishing support provided by: Rolla Publishing Service Center

For more information concerning this publication, contact: Director, USGS South Dakota Water Science Center 1608 Mountain View Road

Rapid City, South Dakota 57702

(605) 394-3200

Or visit the South Dakota Water Science Center Web site at: http://sd.water.usgs.gov/ 



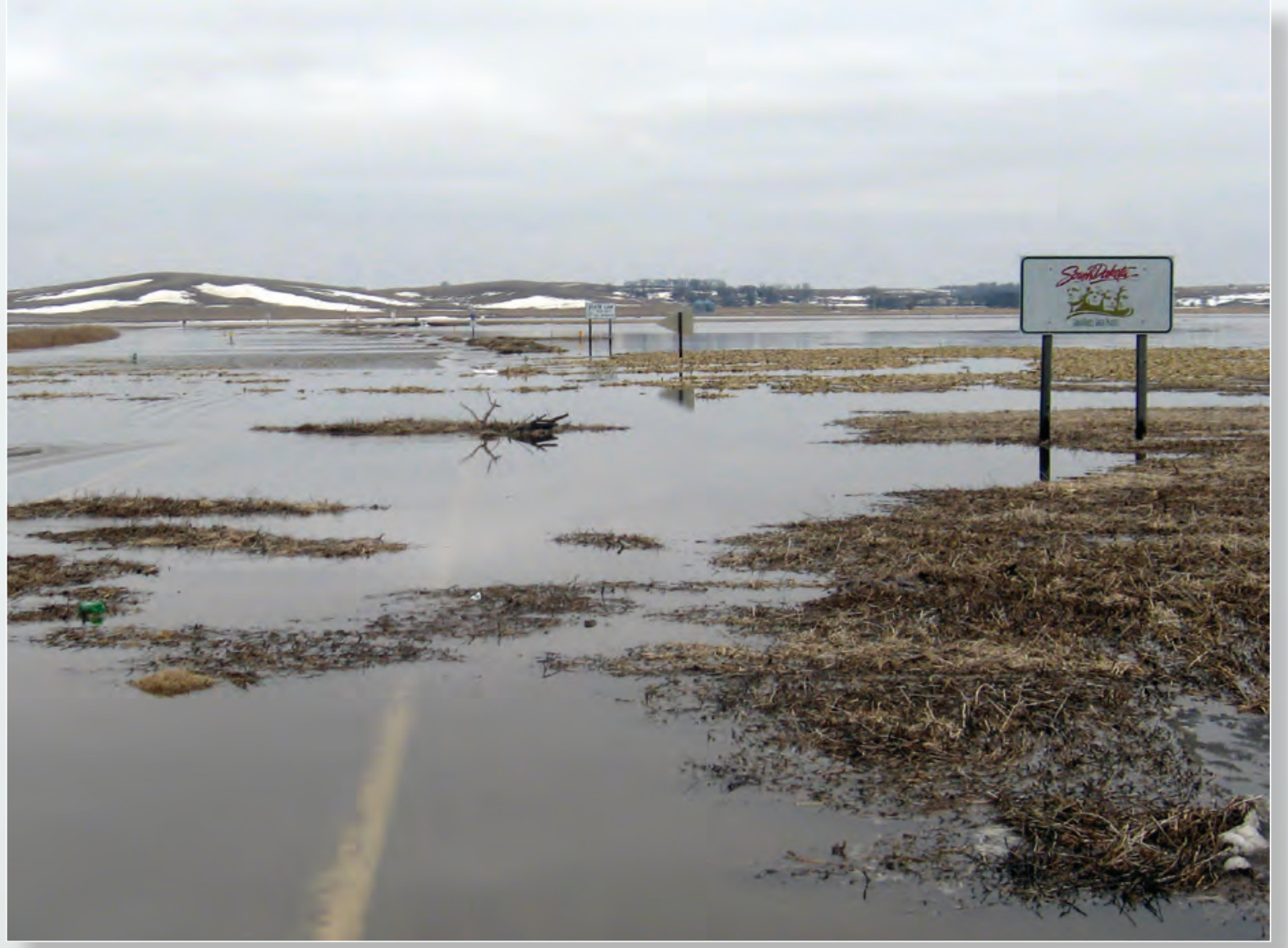

